\title{
4.7 Інноваційно-випереджальна система освіти для підприємницького університету
}

Історія університетської освіти налічує кілька століть, протягом яких вона переконливо продемонструвала свою життєздатність, здатність до змін, сприяння перетворенням і прогресу в суспільстві. Перші університети виникли в Європі в XI - XII століттях і давали в основному гуманітарну освіту. Університет першого покоління - це університет середньовічний, який був заснований дуже давно і зазнав ряд змін. В ті часи викладалися тільки історичні науки, розповідалося, яким чином відбувалося становлення світу. Кількість студентів була невеликою, в межах однієї спеціальності рідко перевищувала число 10. Для керівництва ними зі складу учнів обирався староста десятки - декан (від лат. decem - десять). На чолі університету стояв rector magnificis - simus (лат. rector управитель). Обидві посади займали особи, які мали високий духовний сан. У 1158 р статус університету отримала школа в Болонії (Італія), а потім статус університету було присвоєно школам в Оксфорді та Кембриджі та ін. Незважаючи на те, що освіта тільки починала здобувати свою популярність в суспільстві, випускники перших факультетів вже допомагали вирішувати основні державні завдання: брали участь в управлінні державою і підтримці правопорядку, забезпечували розвиток духовного життя суспільства і охорони здоров'я.

Від самого початку університети і університетська освіта не мали яскраво виражених національних традицій і спрямованості. Біля витоків сучасної університетської освіти лежать дві протилежні тенденції: одна - націленість на отримання та тиражування знань; інша - прагнення отримати практичну, висококласну, професійну підготовку. Ці дві тенденції дали початок двом основним теоріям розвитку університету: теорії ліберальної і теорії утилітарної освіти. Прихильники ліберальної освіти, спрямованої на формування духовно вільної особистості на основі вивчення класичної літератури, вважали, що культурно може розвиватися будь-яка людина незалежно від змін в суспільстві. 
Тому освіта повинна бути спрямована на потреби окремої особистості, а не суспільства вцілому.

Інших поглядів дотримувалися утилітаристи. Вони на перший план висували корисність освіти. Система освіти повинна бути доступна всім, вирішувати нагальні соціальні проблеми і не обов'язково розвивати внутрішній світ окремої особистості.

Суперечки утилітаристів і прихильників ліберальної освіти тривали кілька століть і тільки в XIX столітті завдяки реформам В. фон Гумбольдта в теорії університетської освіти була зроблена спроба об'єднати погляди опонентів, з'єднати потреби суспільства і окремої особистості в процесі здобуття освіти. 3 цього часу роль і значення вищої освіти ще більше зростає, воно стає не просто знанням окремих людей, а починає приносити користь всьому суспільству. Нова модель університетської освіти - це університет другого покоління - це класичний університет, основна ідея якого сформована Гумбольдтом в відомому меморандумі: вищий навчальний заклад - «не що інше, як духовне життя людей, дозвілля або внутрішне прагнення яких призводять до науки і досліджень». ${ }^{1}$ При цьому відносини викладача і студента засновані тут на принципі спільного служіння науці, внесення свого вкладу в осягнення істини, а держава проводить політику невтручання, лише забезпечуючи інфраструктуру та підтримуючи достаток людей, що вибрали науку як життєве покликання. В основу нової моделі університетської освіти були покладені три принципи. Перший полягав у запереченні примітивного утилітарного погляду на освіту, коли знання цінуються лише 3 практичної точки зору. Другий - застерігав від засилля дослідної (емпіричної) науки, яка протидіяла фундаментальному теоретичному пізнанню. Нарешті, третій принцип стверджував перевагу гуманітарної освіти, без якої не може бути освіченої особистості².

\footnotetext{
${ }^{1}$ Гумбольдт В. О внутренней и внешней организации высших научных учреждений в Берлине. Неприкосновенный запас. 2002. № 2 (22). URL : http: //ecsoc

2 Захаров И. В., Ляхович Е. С. Миссия университета в европейской культуре. M., 1994. 85 c.
} 
В основу Гумбольдської моделі університету покладені ідеї німецької класичної філософії від Канта і Фіхте до самого фон Гумбольдта. Виникнення нової моделі відбувалося одночасно 3 підйомом національних прагнень і підвищенням значення держави в XIX столітті. Між владою і наукою склалася домовленість. Вчені бажали мати дозволені державою безпрецедентні інституційні можливості. У свою чергу держава ставила вимога до університетів щодо підтримки національної культури, допомоги у формуванні національних символів, особистості громадян своєї держави. Тому в основі формування «ідеальної моделі» університету лежить союз між освітою і владою.

«Ідеальна модель» університету - це, насамперед, культурно-історична модель, згідно з якою університет залежить від соціокультурного оточення. Суспільство й культура, в яких виникає університет, визначає його форму, завдання, функції, висуває певні вимоги.

Ефективне функціонування нової моделі університету з одного боку, i зміни соціально-економічних і політичних тенденцій в державі і світі дозволили змінити місце і роль університету.

У 1998 р. дослідник вищої освіти Бертон Кларк запропонував ідею «підприємницького університету» ${ }^{3}$ як «усвідомленого зусилля по створенню інституту, яке вимагає цілеспрямованої роботи і напруги», де головним принципом $€$ «прийняття ризиків при освоєнні нових практик, результат яких не визначений» ${ }^{4}$.

Університет третього покоління в інтерпретації Й. Вісеми ${ }^{5}$ або підприємницький університет в термінології Б. Кларка, повинен не тільки реалізовувати свою суспільно значиму функцію, а й відповідати конкретним запитам бізнесу і держави. Ця концепція - продукт XX століття, наслідок ряду

\footnotetext{
${ }^{3}$ Кларк Б. Создание предпринимательских университетов. М. : Изд-во ГУ ВШЭ, 2011. $240 \mathrm{c}$.

${ }^{4}$ Clark B. Collegial Entrepreneurialism in Proactive Universities: Lessons from Europe. Change. 2000. Vol. 32. No. 1. Pp. 10-19. URL : man. hse.ru/univman/msg/144983.html ${ }^{5}$ Wissema J. Towards the Third Generation University: Managing the University in Transition. Cheltenham: Edward Elgar, 2009. 272 p.
} 
фундаментальних змін, що закріпили нові форми відносин між наукою i суспільством. Зокрема, можна відзначити:

(a) посилення приватного сектора у виробництві наукового знання, стрімке зростання числа і якості дослідних проєктів в недержавній сфері, коли потенціал корпоративних дослідних відділів навіть в області фундаментальних досліджень практично зрівнявся з державними; i

(б) збільшення значимості регулювання державної та міжнародної політики в області науки і технології, викликане не тільки глобальними проблемами сучасності, але і закріпленням сцієнтизму в ідеологічному плані (П. Бурдьє, Ю. Хабермас та ін.), а також формуванням нових форм «громадянської відповідальності» і посиленням суспільних інтересів в цій області. Зазначені чинники змінили підстави, на яких до того будувався соціальний контракт між наукою і суспільством. У епістемологічному сенсі авторитет науки по суті не змінився, але сталася зміна парадигми розвитку університетів, сформувалася концепція «академічного капіталізму». Під «академічним капіталізмом» розуміють весь спектр дій університету, спрямованих на пошук додаткового фінансування як для функціонування установи, так i для реалізації індивідуальних дослідницьких проектів ${ }^{6}$.

Основний агент академічного капіталізму - підприємницький університет - $€$ по суті велика капіталістична корпорація, становлення якої визначається перетворенням формального підпорядкування академічної праці капіталу в реальний. Вітчизняна вища освіта поки в меншій мірі порушена цим процесом, ніж сфера академії в розвинених країнах Заходу, і страждає швидше від спадщини минулого, ніж від тенденцій перетворення вищої освіти в сферу реального підпорядкування праці капіталу.

Багато століть вища освіта розглядалася як суспільне благо, і викладачам вдавалося зберігати певну дистанцію між потребами ринку та тими знаннями, які вони дають в університеті. Ситуація почала змінюватися в 1980 - ті р., коли

\footnotetext{
${ }^{6}$ Slaughter S., Leslie L. Academic Capitalism: Politics, Policies and the Entrepreneurial University. Johns Hopkins UP: 1997. $296 \mathrm{p}$.
} 
виникла економіка знання, в якій конкуренція грунтується швидше на інтелектуальних властивостях людей, ніж на їх фізичних здібностях і природних ресурсах країни.

Функції університету також стали змінюватися разом з фундаментальними економічними і політичними змінами. С. Слотер і А. Леслі ${ }^{7}$ бачать в глобалізації чотири далекосяжних наслідки для вищої освіти:

1) скорочення грошей, доступних для вільного використання університетом;

2) збільшення ролі технологічних наук і тих напрямків, які тісно пов'язані 3 ринком; однак, в західній літературі зазначається, що $є$ інститути i департаменти, які легше і швидше зможуть знайти собі зовнішнє фінансування (технічні напрями і економіка), а є напрямки досліджень, зокрема соціальні i гуманітарні науки, які можуть відчувати певні складності. Всередині університету вони відіграють роль оплоту академічної культури, і тут дуже важливо адекватно оцінювати тенденцію на видалення 3 навчальних планів гуманітарних дисциплін;

3) посилення взаємодії між транснаціональними корпораціями та державними структурами в області розробки нових продуктів та інновацій;

4) збільшується конкуренція транснаціональних корпорацій і промислових країн в сфері інтелектуальної власності.

Отже, підприємницький університет докорінно змінює свої характеристики:

1) займається фундаментальними дослідженнями, що формують основу будь-якого прогресу, не тільки в області науки, але також в сфері економіки;

2) багато років тому дослідження було сфокусовано на одній дисципліні. Зараз акцент робиться на міждисциплінарність. Наприклад, дослідження Центру регіонального розвитку університету та Центру стратегічної аналітики та антикорупційного менеджменту. Основними завданнями Центру регіонального

\footnotetext{
${ }^{7}$ Slaughter S., Leslie L. Academic Capitalism: Politics, Policies and the Entrepreneurial University. Johns Hopkins UP: 1997. $296 \mathrm{p}$.
} 
розвитку є: моніторинг актуальних міжнародних програм і проектів міжнародної технічної допомоги які спрямовані на регіональний розвиток; консультування та допомога у розробці грантових проектів для подання у міжнародні фонди; участь у підготовці цільових програм та грантових проектів; участь у підготовці та здійсненні заходів щодо реалізації регіональних цільових програм, тощо. Центр є полігоном для підготовки фахівців спеціальностей: публічне управління та адміністрування, економіка, менеджмент.

У Центрі регіонального розвитку університету виконувались роботи на замовлення Міністерства регіонального розвитку, будівництва та житловокомунального господарства України; Департаменту комунального господарства Харківської міської ради; Балаклійській, Барвінківській та Ізюмській районних адміністрацій.

Центр стратегічної аналітики та антикорупційного менеджменту утворений 3 метою вдосконалення навчального та науково-методичного забезпечення підготовки фахівців зі спеціальності облік і оподаткування безпеки; інформаційно-аналітичної та антикорупційної діяльності для підприємств, установ, організацій; сприяння розвитку недержавної системи безпеки та їі імплементації до системи національної безпеки України, утворення системи підготовки, перепідготовки та підвищення кваліфікації фахівців 3 безпеки, антикорупційної діяльності, обліку i аудиту для державного та приватного секторів економіки.

3) Тісна співпраця 3 промисловими компаніями, які згодом виведуть наукові розробки університету не тільки на внутрішній, але і на міжнародний ринок. Наш ууніверситет підписав угоду про співпрацю між навчальним закладом та АТ «Турбоатом». Мета підписання документу - взаємодія університету i «Турбоатома» в питанні інтеграції наукового, освітнього i виробничого потенціалу для виконання спільних науково-дослідних, освітніх проєктів та робіт інноваційного характеру з пріоритетних напрямків розвитку науки, техніки і технологій в сферах енергетичної інженерії, автоматизації технологічних процесів, зокрема, рішення задач енергоефективності. Угода 
дозволить підвищити рівень дослідження та інноваційних розробок, якість навчального процесу при підготовці студентів, аспірантів і докторантів, а також якість кадрового забезпечення навчального процесу, наукових досліджень та інноваційних розробок. Крім цього, забезпечить умови ефективного використання наукового та матеріально-технічного потенціалу університету та «Турбатома» для вирішення актуальних соціально-економічних проблем.

Так, на базі кафедри хімії інтегрованих технологій нашого університету відкрито нову дуальну магістерську програму «Технології та дизайн кераміки та скла», яка включає дві основні складові: аудиторно-лабораторну підготовку в університеті та одночасне працевлаштування студентів на ПАТ «Харківський плитковий завод». А лабораторний центр «Centr ceramic laboratory» тa Laboratory «Paints. Varnishes. Coatings» дозволяють студентам займатися науководослідною роботою, що відповідає сучасним викликам.

4) Важливо розуміти, що університет третього покоління - це відкритий університет. Він не тільки повинен працювати під егідою Міністерства освіти, але також бути відкритим промисловості, новим студентам, нової моделі освіти і виховання.

Таким новим для вузу, на наш погляд, $є$ облік теорії поколінь як методології освіти і виховання.

Теорія поколінь - це нове вчення, що інтенсивно розвивається i застосовується практично. Рушійною силою історичних подій багато хто вважає зміну поколінь (О. Кант, Дж. Мілль, Г. Феррарі, О. Лоренц). Альтернативна точка зору, згідно з якою зміна поколінь $є$ наслідком історичного процесу, була вперше чітко сформульована німецьким філософом В. Дильтеєм в роботах, опублікованих у 60-70-ті роки XIX ст. Існує багато різних точок зору у визначенні поняття «покоління». Ми під поколінням будемо розуміти сукупність однолітків зі схожими цінностями, що формується в певний історичний період під впливом одних подій і схожих соціальних норм ${ }^{8}$. Таким чином, крім

\footnotetext{
${ }^{8}$ Радионова Л. А. Теория поколений и воспитательная работа в современном вузе. URL :

https://core.ac.uk/download/pdf/78068467.pdf
} 
демографічної, історичної, хронологічної і символічної детермінант в розгляд буде включений аксиологічний підхід до диференціації поколінь.

У такому контексті теорія поколінь розглядалася американськими вченими Нейлом Хоув і Вільямом Штраусом. В основі цієї теорії - цінності людей, саме цінності і їх схожість, а не вік формують і визначають покоління. Розрізняють: «мовчазне» покоління (1923-1943 роки народження), покоління «бебі-бумерів» (1943-1963 рік народження), покоління Х (1963-1983), покоління Y (1983-2000), покоління Z (2000-2020) 9 .

Теорія поколінь передбачає аналіз співіснування наступних життєвих вимірів в освіті: покоління Y i Z це і є наші студенти, і покоління «бебі-бумерів» - викладачі. Соціокультурне середовище відносин між поколіннями або скорочує дистанцію між ними, або спричиняє тотальне дистанціювання, що призводить до кризи. Спроба уникнути ці крайнощі спонукала філософів на обгрунтування «етики дискурсу» - вчення про моральність, яке змістом своєї роботи ставить проблеми комунікації і дискурсу. Саме «етика дискурсу» орієнтує представників різних поколінь не на розбрат і деградацію, а на єдність, відповідальність, згоду, на комунікацію. Йдеться про співпрацю. Викладач в змісті і способі побудови навчального предмета відображає не тільки поняття, закони, теорії та факти, а й спосіб мислення, властивий даному етапу його розвитку і ті методи пізнання, які застосовуються в науці. Такий системноструктурний підхід до побудови змісту дозволяє студентам, не втрачаючи часу на вивчення кожного окремого випадку, бути підготовленим до самостійного освоєння всіх таких випадків, причому не тільки відомих, але й тих, які з'являться в майбутньому. Тому, освітній процес поступово стає адаптивним і повинен все більше прискорювати темпи та включати те, що з'явиться або може з'явитися в майбутньому. До IQ i EQ потрібно додати AQ - адаптивний інтелект, здатність до адаптації. Адаптивність як здатність прийняття змін.

\footnotetext{
${ }^{9}$ Шамис Е., Антипов А. Теория поколений. Маркетинг Менеджмент. 2007. № 6. URL: http://old.executive.ru/publications/
} 
У сучасній культурі присутній яскраво виражений шар інновацій, який постійно зламує і перебудовує культурну традицію, ускладнюючи тим самим процеси соціалізації і адаптації людини до постійно мінливих умов і вимог життя. Ускладнення соціокультурної реальності супроводжується зламом традицій і норм. I проблема це не біологічна, а соціокультурна.

Це проблема зміни способів і типів наступності, відмови від наступності, знищення традицій, а значить i руйнування культури. Культура може розвинутися, лише спираючись на традиції. Зміна типів наступності, відносини до традиції зовсім не пов'язана з запереченням власної історії, вона передбачає вироблення ідеалу та пошук адекватних йому способів життєдіяльності.

Наш час несе в собі культ молодості. Наприклад, представники авангардизму вбачають у молодіжній контркультурі єдино надійну, ефективну, радикальну опозицію щодо всього застійного, консервативного в суспільстві. Цінність людини визначає вміння швидко $\mathrm{i}$ ефективно діяти, легко пристосовуватися до нових технологій та інновацій. Сьогодні спостерігається культ темпу новизни. Як цей культ проявляється в системі взаємозв'язків студент - викладач?

Зараз ключові позиції в вузі займають представники покоління бебібумерів - існує чітка різниця між ними і наступними поколіннями. Головне питання освіти і виховання - як забезпечити спадкоємність між поколіннями, щоб відхід бебі-бумерів не спричинив за собою втрату унікальних знань і відносин.

Одна 3 ключових цінностей покоління бебі-бумерів - «бути молодими». Поняття «молодості» пов'язане у представників цього покоління з позитивними емоціями про їх власну молодість, яка включає досвід втілення великих планів і гігантських будівництв в масштабі країни, а також грандіозних подій загальнолюдського масштабу - як, наприклад, політ людини в космос. Крім того, молодість цього покоління була наповнена активним дозвіллям - походами, а також підприємницьким і лідерським досвідом - комсомолом, будзагонами, суботниками. Бебі-бумерам подобається «бути молодими» в різноманітних 
сценаріях - відчувати себе молодими, виглядати молодо i спортивно, розбиратися в молодіжних питаннях, бути 3 молоддю. Результати впливу цінності «бути молодим» проявляються різних аспектах та все ж є області, де ця цінність перебуває ніби «у себе вдома»: це освіта.

Сьогодні у вузі покоління студентів Y змінюється поколінням Z, поки тільки на молодших курсах, це особливо актуалізує не просто розуміння цінностей покоління Z, а й зміна парадигми університетської освіти. У покоління $\mathrm{Z}$ проявляється гіперопіка - вони постійно знаходяться під наглядом дорослих. Після школи вони займалися в гуртках або з репетиторами, в результаті «зети» відчувають дефіцит спілкування з однолітками. У гаджетах і технологіях вони розбираються краще, ніж в емоціях людей. Тут викладачі університету повинні бути гранично обережними.

Брак спілкування з зовнішнім світом часто компенсується увагою до свого внутрішнього світу, і студенти покоління $Z$ активно цікавляться мистецтвом $\mathrm{i}$ наукою. 40\% «зетів» визнають, що для них важливіше справний Wi - Fi, ніж справні крани у ванній. Поколінню $\mathrm{Z}$ не довелося бути свідками створення $\mathrm{i}$ розвитку соціальних мереж, технології миттєвого обміну повідомленнями, смартфонів, пошукових систем і мобільної революції, вони при них народилися. Зв'язок з будь-якої точки, вільний доступ до глобальної інформації, будь-яке відео за запитом, новини 24/7 - це звичний світ для «зетів». Їм, звиклим 3 дитинства до візуальної інформації, складніше сприймати тексти, а це вимагає перебудови всієї вербальної культури викладання у ВНЗ.

Якщо студенти мілленіали вивчили соціальні мережі, стали публікувати свої думки, висловлювати свою думку і повідомляти всьому світу про кожну значимому подію свого життя. Покоління $Z$ діє 3 міркувань безпеки i самозбереження, поводиться стриманіше і викладає в інтернет тільки обрану інформацію. Щорічно в курсі соціології студенти нашого університету отримують практичне завдання - аналіз параметрів i факторів для самостратифікації, так зовсім недавно мілленіуми називали в показнику «час в 
соціальних мережах» - до 12 годин. Сьогодні «зети» не називають більше 8 годин (це максимальні показники).

Покоління Z - реалісти: вони живуть не тільки в умовах глобальної економічної кризи, а й системної кризи в нашій країні. Згідно з даними фонду Pew Charitable Trusts, за час Великої рецесії середній рівень добробуту батьків «зетів» знизився приблизно на $45 \%{ }^{10}$, а в нашій країні показник витрат тільки на їжу становить $50,3 \%{ }^{11}$.

Мілленіали вагаються - чи варто було вкладати стільки сил і грошей у вищу освіту? Особливо враховуючи, що 44\% вузівських випускників працюють за фахом, який потребує престижного диплому, а кожен восьмий випускник безробітний. Покоління Z прагне до освіти, їм цікаво отримувати знання в різних форматах: навчання на вимогу (on - demand learning) або навчання точно в строк (just - in - time learning) - наприклад, курси на YouTube.

Соціологічне дослідження, яке ми проводили серед студентів першого курсу в вересні 2020 році, показало: на питання про причини вступу до нашого університету першокурсники покоління Z назвали «можливість стажування, практики за кордоном, подвійних дипломів» - 39\%, а в 2015 таких було (мілленіалів) менше 10\%. «Зети» орієнтовані отримати будь-який цінний досвід в різних ролях або проєктах під час навчання в університеті. Відповіді по альтернативі: «Вкажіть, які можливості, що надаються університетом, хотіли б Ви використовувати для особистісного розвитку» розподілилися таким чином: «додатково вивчати іноземні мови» передбачувано переважають - майже 57\%. Друге місце - «брати участь в міжнародних навчальних програмах» майже 42\%. Третє місце - «відвідувати спортивні секції» - більше 34\%. Майже 34\% наших студентів хочуть отримати водійське посвідчення.

\footnotetext{
${ }^{10}$ Ryan Jenkins, HR Daily Advisor. Generation Z vs. Millennials: The 8 Differences You Need to Know By Ryan Jenkins, Author. International Keynote Speaker Sep 25, 2017 HR Management URL :

https://hrdailyadvisor.blr.com/2017/09/25/generation-Z-vs-millennials-8-differences-need-know/

${ }^{11}$ Стало відомо, скільки українці витрачають на їжу URL : https://economics.unian.ua/finance/10250745-stalovidomo-skilki-ukrajinci-vitrachayut-na-jizhu.html
} 
I природно, «Зети» підуть в більш відкритий вуз, який може запропонувати їм більше можливостей для подальшої роботи, для наукової діяльності, а підготувати їх до цієї ролі повинен університет 3.0.

5) В університеті повинен бути визначений масштаб діяльності. В іншому випадку він не зможе успішно працювати: повинні бути бібліотека, лабораторії, інфраструктура, які забезпечать якість освіти. Наш університет приділяє цьому пильну увагу. Так на кожному факультеті є сучасні лабораторії, що відповідають передовим досягненням науки і техніки. Наприклад, галузева науково-дослідна лабораторія по обстеженню та випробуванню будівельних конструкцій та матеріалів кафедри будівельних конструкцій. У лабораторії виконуються дослідження і роботи на замовлення: Міських рад; Обласних державних адмінінстрацій; ОТГ та районих адмінінстрацій; ТОВ «Стальконструкція ЛТД»; ДП «УкрНТЦ «Енергосталь»; «ЖБК Авантаж»; ТОВ «Житлобуд-1»; ТОВ «Житлобуд-2». У Харківському національному університеті міського господарства імені О. М. Бекетова вже понад п'ять років студенти можуть працювати в сучасній лабораторії BIM технологій. BIM - це, в широкому розумінні, віртуальне будівництво, інформаційне моделювання майбутніх будівельних об'єктів. Одним 3 перших провайдерів VDC послуг у світі стала харківська команда UA Team. Саме в рамках співпраці з цією компанію у 2014 році було відкрито перший в Україні навчальний центр з ВІМ на базі ХНУМГ ім. О. М. Бекетова. Тоді це був офлайн курс, що проходив в лабораторії, оснащеній за останніми потребами, із залученням практикуючих спеціалістів. Після закінчення курсу 18 людей приєдналися до команди, що стало значним поштовхом розвитку компанії ${ }^{12}$.

Вже декілька років Харківський національний університет міського господарства імені О. М. Бекетова активно співпрацює з Національною енергетичною компанією «Укренерго». Університет для цього має потужну інфраструктуру - провідні лабораторії і центри університету, які забезпечують

\footnotetext{
${ }^{12}$ Офіційний сайт Харківського національного університету. URL : https://www.kname.edu.ua/index.php/ru/
} 
підготовку фахівців зі спеціальності електроенергетика, електротехніка та електромеханіка. Це лабораторія альтернативної енергетики, лабораторія інтелектуальних систем управління освітленням, лабораторія «Електрообладнання систем міського електропостачання», лабораторія цифрового релейного захисту та автоматики, науково-дослідний Центр світлотехнічних вимірювань, лабораторія світлового дизайну, інноваційна освітньо-наукова лабораторія «Сонячна електростанція» та інші. Лабораторії призначені для забезпечення потреб університету в електричній енергії, підготовки студентів та проведення наукових досліджень. На їх базі студенти отримують теоретичні і практичні навички проектування і обслуговування такого виду електроустановок. Напрямками діяльності лабораторій є ефективна підготовка докторантів, аспірантів, магістрів та бакалаврів 3 акцентом на міждисциплінарність; підготовка персоналу енергопостачальних компаній, промислових, транспортних та житлово-комунальних підприємств за наступними програмами підвищення кваліфікації для спеціалістів.

На факультету інженерних мереж та екології міст створений уніфікований лабораторний комплекс «Еколого-енергетичної безпеки». Центр включає лабораторію інноваційних енергозберігаючих технологій та лабораторію екологічного моніторингу. $\mathcal{C}$ також лабораторія «Видобування і підготовки нафти і природного газу», лабораторія «Транспортування нафти і природного газу», лабораторія газових та теплових систем і кондиціювання повітря.

Факультет архітектури, дизайну та образотворчого мистецтва створений сучасний комплекс архітектурно-художніх майстерень і лабораторій «Arhouse». Комплекс створено з метою забезпечення сучасних умов навчання студентам архітектурного та художнього напрямів підготовки із урахування особливостей та тенденцій сучасної освіти. До архітектурно-художніх майстерень «Arhouse» входять: лабораторія комп'ютерного моделювання; майстерня малюнка i живопису; скульптурна майстерня; лабораторія архітектурного моделювання; ландшафтно-архітектурна майстерня; виставковий зал; конференц-зал; студентське архітектурно-проектне бюро. 
На факультету транспортних систем та технологій створено лабораторію навчального центру SmaLog «Розумний транспорт і логістика для міст». Лабораторію створено в рамках реалізації міжнародного проекту програми КА2 «Еразмус+». Під час навчання в лабораторії за допомогою програм Vissim, Visum, Anylogic, StatGraphic можна виконувати наступні види робіт:

- аналізувати параметри i показники функціонування транспортних процесів і систем;

- проводити дослідження транспортних технологій на основі моделювання транспортних процесів.

- проводити моделювання транспортних потоків;

- розробляти технології логістичного управління на транспорті;

- оцінювати ефективність управління транспортними технологіями;

- проводити дослідження фактору людини на транспорті;

- виконувати статистичний аналіз ймовірнісних процесів.

6) Дуже важливо, щоб всі в університеті вміли розмовляти англійською мовою, іншими іноземними мовами. Так, в Харківському національному університеті міського господарства дуже активно діють міжнародні культурноосвітні та мовні центрі: Українсько-канадського культурно-освітнього центру;

Українсько-польського культурно-освітнього центру; культурноосвітнього центру «Інститут Конфуція»; Чеського мовно-культурного центру; Українсько-Азіатського культурно-освітнього центру; Українсько-Турецького культурно-освітнього центру; Українсько-Арабського культурно-освітнього центру; Лівансько-українського культурно-освітнього центру. Це створює можливості для участі в програмах студентських обмінів, долучення до міжнародних наукових програм, участі у культурних заходах, що проводяться міжнародними центрами протягом навчального року.

7) В університетах другого покоління займалися, в першу чергу, академічною діяльністю, а тільки потім наукою. Зараз ситуація змінилася: в університетах третього покоління першочергово виходить виробництво i комерціалізація розроблених ноу-хау. Це актуалізує такі питання, як захист 
інтелектуальної власності. За останній час в університеті здійснено суттєве покращення патентно-ліцензійної роботи. Так, наприклад, на кафедрі електричного транспорту налагоджено інтенсивну роботу з підготовки об'єктів інтелектуальної власності, завдяки чому тільки за період з 01.01.2019 р. по 10.01.2020 p. науково-педагогічними працівниками кафедри електричного транспорту отримано 96 патентів України із загальної кількості 111 по університету.

8) В університетах третього покоління - децентралізація: в більшості країн університети не можуть самостійно розробляти освітні програми, видавати власні дипломи. Для цього вони повинні отримати дозвіл від міністерства. За оцінками західних дослідників, в майбутньому ця ситуація зміниться. Університети будуть, як і раніше, отримувати фінансування з боку держави, але іншими способами. Всі директиви, які на поточний момент університети отримують від держави, спускаються ректору і далі на професорів, при цьому витрачається дуже багато часу і не дозволяють найбільш ефективно працювати.

Природно, що викладання теж зазнає значних змін. Якісне викладання не менш важливо в порівнянні з якісним дослідженням. Часто наші курси $є$ непопулярними, нецікавими не тому, що предмет нецікавий, а тому що нецікаво працює викладач, неякісно ведеться викладання.

Дипломи, якими ми бачимо їх зараз, теж змінюються. Ступінь бакалавра каже роботодавцю про те, якими знаннями володіє випускник. На поточний момент це не важлива інформація. Тому що роботодавці хочуть найняти певну людину під певний функціонал. Дуже важливо на даний момент, щоб наші випускники відповідали вимогам і щоб вони чітко розуміли, чому вони можуть виконати якісно ту чи іншу роботу.

Таким чином, підприємницький університет, це відповідь вищої освіти на виклики епохи, це зміна моделі функціонування університету в напрямку більшої адаптивності, гнучкості, в напрямку більш активної взаємодії 3 оточенням - державними інститутами, бізнесом, венчурним капіталом, в напрямку створення всередині університетів центрів комерціалізації (трансферу 
технологій, патентної підтримки і захисту, бізнес - інкубації і т. п.), тобто по суті - центрів прибутковості, як це відбувається всередині великих корпорацій, які прагнуть знайти друге дихання на ринку за рахунок внутрішньокорпоративного підприємництва, інтрапренерства.

На наш погляд, кращою ілюстрацією зміни моделі функціонування університету $є$ дослідницький університет Чалмерса ${ }^{13}$, що випустив 40\% шведських інженерів і архітекторів. Він отримує державне фінансування і при цьому приватний з 1994 року. Університет Чалмерса був заснований в 1829 році і за сто з гаком років виріс з промислової школи для бідних дітей у вищу технічну школу, далі виріс спочатку в дослідницький університет, а потім - в підприємницький. Історія приватизації Чалмерса належить до категорії зразково - показових в політиці вищої освіти. У 90-х роках шведський уряд оголосив тендер: вуз, який надасть стратегію розвитку і готовий працювати в контактному режимі, може отримати статус університету - фонду. Ряд вищих навчальних закладів подали заявки, але до кінця дійшов тільки один Університет Чалмерса.

Фонд - це закрите акціонерне товариство, актив, який сам собою володіє, що дозволяє вступати в довготривалі партнерства 3 індустрією, створювати компанії, володіти акціями, дійсно бути інтелектуальною корпорацією. В університеті Чалмерса три управлінських рівні: фонд, наглядова рада і президент зі своєю командою. Члени фонду призначаються урядом, туди входять не тільки представник від індустрії, президент, студенти, викладачі, але й професійний фінансист, політик і літератор. Фонд розпоряджається інвестиціями, наглядова рада вибудовує довготривалу стратегію, президент керує операційною діяльністю. Викладацький сенат, який раніше контролював університет повністю, зберіг за собою лише дорадчий голос.

3 урядом Чалмерс взаємодіє в режимі короткочасних і довготривалих контрактів: гроші в обмін на чіткий план і виконувані обіцянки. Це звична для північноєвропейських країн схема: датські університети домовляються 3

\footnotetext{
${ }^{13}$ Сайт университета Халмерс. - URL : http://www.chalmers.se/en/
} 
міністерством з «контрактами розвитку» на столі, в Фінляндії, наприклад, також є декілька університетів - фондів.

У 1517 році Мартін Лютер прибив 95 тез реформування католицизму на дверях однієї з німецьких церков, поклавши початок Реформації. В університеті Чалмерса прибивання тез перетворилося на академічну традицію. Дисертація публікується у вигляді невеликої книги і урочисто, в колі друзів, іноді з науковим керівником і іншими професорами, іноді без, прилаштлвується або прибивається на стіну так, щоб іï зручно було читати. Із вступу навіть для неспеціалістів в цілому зрозуміло, про що йдеться. В університеті Чалмерса більшість кафе і ресторанів знаходяться в власності Студентського союзу.

Інженерна освіта в Чалмерсі побудована на системі CDIO, Conceive Design - Implement - Operate. Ініціатіва CDIO була розроблена в кінці 90-х у відповідь на невдоволення індустрії рівнем практичної підготовки випускників і офіційно запущена в 2000-му в коллаборації 3 трьома шведськими університетами, включаючи Чалмерс. Зараз в мережі більше ста вузів. Спочатку система відповідала на запит індустрії на більш цілісно підготовлених інженерів і з'єднала дисциплінарні знання, професійні навички, командну роботу і власне здатність розробити інженерний проєкт.

Освітній простір Чалмерса вибудовано як складну матрицю, в трьох вимірах: 13 департаментів, чотири школи, нова система треків. Матриця складалася поступово, крок за кроком. Спочатку існували департаменти, які тримали освітні програми. Потім поступово були введені школи, тепер вони тримають освітні програми, «викуповуючи» курси у департаментів. Це було зроблено, щоб уникнути конфлікту інтересів, коли кафедри намагаються розробляти курси під інтереси своїх викладачів. Нові треки прошивають департаменти i школи по діагоналі, дозволяючи студентам працювати над проєктами, які вимагають різнорідної дисциплінарної експертизи. Матричні рішення схожі на оксамитові революції в організації університету.

Матриця використовується і для організації дослідних робіт. У Чалмерсі є вісім «Зон переваги» (Areas of Advance). Вони також були сформовані недавно i 
проходять крізь департаменти, збираючи компетенції, необхідні для вирішення комплексних завдань в областях транспорту, енергії, виробництва і так далі. «Зони переваги» спрощують вхід для потенційних замовників, чиї проблеми завжди міждисциплінарні ${ }^{14}$.

Університет Чалмерса хоче, щоб на нього дивилися як на партнера номер один - того, кому подзвонять в першу чергу, коли потрібно буде технічне рішення, фахівці з певним набором компетенцій або поради.

У університету Чалмерса багато контрактів з індустрією, але всього16 стратегічних партнерів. В основному це концерни: Volvo, Saab aбо Ericsson. Договори укладаються на $10+$ років, і 3 кожним партнером президент університету зустрічається особисто двічі на рік. Партнерство складно організоване і багаторівневе: контрактні дослідження, запрошені $з$ індустрії професори - практики, стажування, програми «прокачування» персоналу, індустріальні $\mathrm{PhD}$ (рішення задач корпорацій в рамках дисертаційного проєкту) і так далі ${ }^{15}$.

Зростає конкуренція між університетами (за державне i приватне фінансування, за кращих і більш платоспроможних студентів), яку формують рейтингами і ренкінгами. Так в уряді заявили, що «є ціла історія, що потрібно робити з університетами, певною мірою їм передали автономію і повноваження. Ми повинні стимулювати якість і ефективність. Гроші має отримувати передусім той, хто кращий, а не той, кому треба..., у нас з'являться рейтинги університетів i все таке інше» ${ }^{16}$. В міністерстві освіти і науки зазначали, що додаткове фінансування буде виділятися на підставі ряду критеріїв, які повинні «прямо або опосередковано свідчити про те, які університети сильніші, а які слабші». Один 3 них - включення університету в престижні міжнародні рейтинги. The QS World University Rankings ${ }^{17}$. В нашій країні в цей рейтинг входять шість університетів. Зокрема, на 481 позиції рейтингу знаходиться Харківський університет імені

\footnotetext{
${ }^{14}$ Сайт университета Халмерс. - URL : http://www.chalmers.se/en/

${ }^{15}$ Сайт университета Халмерс. - URL : http://www.chalmers.se/en/

${ }^{16}$ В уряді розповіли про плани перебудови фінансування освіти і науки URL:

https://www.unn.com.ua/uk/news/1834855-v-uryadi-rozpovili-pro-plani-perebudovi-finansuvannya-osviti-i-nauki

${ }_{17}$ Рейтинги ВУЗов URL: https://ru.osvita.ua/vnz/rating/64752/
} 
Каразіна (в минулому році - на 401-410 позиціi). Позицію 531-540 займає Київський національний університет імені Шевченка (в 2018 році - 411-420 позиція). Національний технічний університет «Київський політехнічний інститут імені Сікорського» зайняв позицію 601-650 (у 2018 році - 501-550 позиція). Національний технічний університет «Харківський політехнічний інститут» - 701-750 позиція (в 2018 році також 701-750 позиція). Цього року до рейтингу увійшов Львівський політехнічний національний університет, який розділив з Сумським державним університетом 751-800 позиції. У минулому році Сумської держуніверситет зайняв 801-1000 позицію) ${ }^{18}$.

Ще одним критерієм $є$ наукова діяльність. Також в Міносвіти розглядають критерій обсягу позабюджетних коштів, отриманих за наукові замовлення. Четвертий критерій, який буде враховуватися при виділенні додаткового фінансування, - це контингент студентів. «На сьогоднішній день кількість студентів - це найбільш визначальний показник. Кількість студентів впливає на кількість ставок, а за ставками і надають фінансування ... 32020 року контингент студентів буде набагато менше впливати на розмір фінансування. Це потрібно для того, щоб розв'язати руки університетам і викладачам, щоб вони повернули собі святе право відраховувати студентів, які не навчаються. Також ми в контингент вставляємо різні коефіцієнти для спеціальностей. Наприклад, медична спеціальність цінніша, ніж філософія або економіка, тому пов'язана 3 різноманітним обладнанням. Там, де немає додаткових витрат, буде меншим i коефіцієнт (один студент-медик фінансово буде «важити», як три студентаекономіста» ${ }^{19}$.

П'ятий критерій - це «масштаб університету». У Міносвіти його розглядають як «інструмент для об'єднання університетів». «Чим більша установа вищої освіти, тим більше у неї буде грошей. «Ми будемо застосовувати певну градацію - наприклад, «університети до трьох тисяч студентів», «від трьох до шести тисяч» і т. д. Цілком можливо, що буде багато ситуацій, коли при

\footnotetext{
18 Там же

${ }^{19}$ В уряді розповіли про плани перебудови фінансування освіти і науки. URL :

https://www.unn.com.ua/uk/news/1834855-v-uryadi-rozpovili-pro-plani-perebudovi-finansuvannya-osviti-i-nauki
} 
об'єднанні дві установи матимуть більше фінансування, ніж кожен окремо. Тобто, це позитивний стимул об'єднуватися» ${ }^{20}$.

Ще один критерій - зайнятість випускників того чи іншого університету. «3 наступного року ми запустимо моніторинг зайнятості випускників, результат якого так само буде впливати на те, скільки грошей отримає університет. Зрозуміло, що людині після випуску потрібен час на адаптацію, пройде два-три роки, і ми подивимося, де на ринку праці перебуває випускник» ${ }^{21}$.

У контексті вищевикладеного вже відбуваються зміни в структурі та ієрархії ролей і завдань основних акторів університету. У сучасній західній літературі про підприємницький університет досить добре описано. В першу чергу, видимим свідченням вбудовування університетів в суспільство «академічного капіталізму» стає поява багатьох незвичних підрозділів, які доповнюють традиційні структурні одиниці (факультети, школи і т. д.) - такі, як інженерно-технологічні підрозділи, курси підприємництва, центри інкубування бізнесу та ін. Це формує новий вигляд вузів, наближаючи до вигляду багатогалузевих бізнес-корпорацій. Далі, відбуваються важливі зміни в структурі та ієрархії ролей і завдань основних акторів університету, професорів i викладачів. Освітні завдання все більше підпорядковуються завданням досліджень і просування їх результатів. Відповідно, для цього необхідна потужна лабораторна база з новітнім обладнанням і технологами, здатними іï обслуговувати, а також потужні фандрайзингові підрозділи по роботі зі спонсорами та випускниками, які допомагають залучати кошти для фінансування досліджень. Наприклад, Центр трансферу технологій «Мегаполіс» в нашому університету створено за фінансової підтримки Фінансовопромислової групи DCH, друзів, випускників та студентів Університету. В основу діяльності Центру трансферу технологій «Мегаполіс» закладено принципи наукової кооперації, вільного доступу до ресурсів, міждисциплінарних досліджень, що сприяють підвищенню наукового та

\footnotetext{
20 Там же

${ }^{21}$ Там же
} 
науково-технічного потенціалів студентів, аспірантів, докторантів та викладачів Університету.

Роль такого «допоміжного» персоналу для успішного функціонування університету стає настільки ж важливою, як і роль академічного персоналу.

Нарешті, все частіше викладачам доводиться брати на себе, крім «академічних» також «неакадемічні» функції, тобто відбувається втрата розмежувань між ролями і формування якогось сукупного працівника вищої освіти.

На цьому тлі, природно, відбуваються і зміни в сфері організаційної та корпоративної культури. Традиційний університет представляв собою особливий вид громадського інституту, який відрізнявся від комерційних організацій, виступаючи свого роду «вежею зі слонової кістки» для тих інтелектуалів, кому не близькі цілі і цінності зовнішнього світу. Ця відмінність підкреслювалося академічної свободою - незалежністю університету від зовнішніх впливів і колегіальністю як особливим способом організації внутрішньої діяльності. «Підприємницькі» ж університети стали втрачати цю свою колишню ідентичність.

На зміну горизонтальному академічному самоврядуванню в багатьох сферах життя університетів приходить вертикальне «управління за результатами»; на зміну обраним 3 числа самих професорів тимчасових керівників - наймані менеджери від освіти; на зміну атмосфері задумливого відокремлення - атмосфера пошуку швидкого результату, ринкової ефективності. Сучасні умови функціонування університетів, а також досвід перших університетів підприємницького типу дозволяють позначити основні джерела додаткових коштів, що залучаються вузом:

- збільшення приватних пожертвувань, в тому числі створення цільових фондів - ендаументів; Так, ендаумент Гарварда заробляє 35\% прибутків університету 22.

\footnotetext{
22 Акции, стартапы, недвижимость: куда инвестируют Гарвард, Йель, Стэнфорд и другие зарубежные университеты. URL : https://www.rvc.ru/press-service/media-review/venture/157912/
} 
- розвиток нових форм навчання (онлайн, корпоративного, контрактного і т. д.);

- розвиток торгівлі на території студентського містечка;

- введення карт оплати і електронних карт на території студентського містечка;

- розробка програм для випускників;

- надання в оренду майна на території студентського містечка;

- доходи від прав на інтелектуальну власність (результати дослідницької роботи).

Політика академічного капіталізму, що проводиться в університетах, поставила їх перед дилемою часткової відмови від академічної свободи на користь діяльності, спрямованої на залучення додаткових коштів, необхідних для забезпечення наукового та освітнього процесів. Зокрема, це виражається в необхідності вибирати напрямок дослідження, що представляє інтерес: для самого дослідника, для бізнесу (комерційних структур, промислових підприємств) $)^{23}$.

Зі зміцненням ринкової логіки в сфері вищої освіти стало вкорінюватися поняття «новий менеджеріалізм» («нове управління»), яке означає прийняття структурами громадського сектора тих організаційних форм i технологій, управлінських практик i цінностей, які існують в сфері приватного підприємництва ${ }^{24}$. Менеджеріалізм характеризує принципи управління, прийняті в приватних корпораціях, але поширювані на державні і громадські інститути ${ }^{25}$. Розвиток ідей менеджеріалізма в останнє десятиліття пов'язаний з проникненням неоліберальних принципів в державне управління та суспільний сектор. Зміни в системі управління вузом пов'язані з введенням моделі управлінських рішень «зверху вниз», а також 3 укоріненням самого поняття «менеджмент

\footnotetext{
${ }^{23}$ Прохоров А. В. Влияние ценностей академического капитализма на функционирование современных университетов. Вестник ТГУ. Сер. «Гуманитарные науки». 2012. № 5. С. 271-278.

${ }^{24}$ Мирча М. Институциональные подходы к предпринимательству: анализ и опыт университета Бабеш-Больяй в Клуж-Напоке. Высшее образование в Европе. 2006. Т. XXXI, № 2.

25 Абрамов, Р. Н. Менеджериализм и академическая профессия. Конфликт и взаимодействие. Социологические исследования. 2011. № 7. С. 38.
} 
університету». Сфера вищої освіти зазнала змін, для яких Дж. Келлер запропонував формулювання «управлінська революція в університеті» («the management revolution in the academy»). В результаті «революції» управлінська ланка університету змушена посилити стратегічний контроль над діяльністю вузу і його підрозділами ${ }^{26}$.

Ухвалення ідей нового менеджеріалізма пояснює посилення уваги до проблеми управління діяльністю i внутрішньою культурою університету. Керівник вузу тепер розглядається не тільки як академічний лідер, але і як управлінець штатом, студентами, фінансами, системою викладання. Ускладнення університетської структури в умовах менеджеріалізму пов'язане 3 появою професійних груп всередині вузу, які мають власні уявлення про пріоритети університетського життя. Новий менеджеріалізм виступає умовою виникнення ціннісних протиріч між представниками менеджменту i академічного персоналу. Для академічної спільноти ключовою цінністю є науково-дослідницька робота, результати якої можуть виражатися у вигляді публікацій. Представникам адміністративного персоналу важливим $\epsilon$ дотримання процедур і формальних інструкцій, що упорядковують управління університетом ${ }^{27}$. Протиріччя менеджеріалізму в університетському середовищі пов'язано 3 дилемою «ефективне управління - академічна свобода», яка відображає цінності «адміністраторів» в першому випадку і «академіків» - у другому.

Дослідження діяльності вузів Великобританії продемонстрували, що зміни, які відбуваються в культурі та цінностях вищої школи, як правило, виражаються в появі нових цінностей i ̈̈х співіснування поруч зі старими (традиційними) цінностями. Новий менеджеріалізм зачіпає, 3 одного боку, організаційну культуру університету (організаційну структуру, систему управління, стиль управління), з іншого боку, об'єктом уваги стає корпоративна

\footnotetext{
26 Дим Р. «Новый менеджериализм» и высшее образование: управление качеством и продуктивностью работы в университетах Великобритании. Вопросы образования. 2004. № 3. С. 38

${ }^{27}$ Мирча М. Институциональные подходы к предпринимательству: анализ и опыт университета Бабеш-Больяй в Клуж-Напоке. Высшее образование в Европе. 2006. Т. XXXI, № 2. С. 46.
} 
культура (цінності, норми академічної спільноти) і ціннісні основи функціонування університетів.

Новий менеджеріалізм ставить перед академічною спільнотою кілька складних виборів, пов'язаних:

- зі співіснуванням старих і нових типів управлінських структур;

- 3 поєднанням різних стилів управління, наприклад «м'яких» $\mathrm{i}$ «жорстких» форм управління;

- зі зміною характеру відносин між управлінцями і «підлеглими»;

- 3 поєднанням старих i нових цінностей внутрішньої культури університету.

Які ж реалії України в реалізації концепції підприємницький університет? Біди переважної більшості наших вузів не в «академічному капіталізмі», який в Україні поки відомий в основному з чуток, а в «успадкованих лихах», тобто у вкоріненій інституційній інерції, збереженні принципів і практик, які майже в незмінному вигляді перекочували з радянських вузів - виробників кадрів для соціалістичної індустрії.

У вузівському співтоваристві спостерігаються дві тенденції: з одного боку, передова частина вузівської спільноти активно просуває нові формати навчання, включаючи онлайн-курси, формує інноваційну інфраструктуру, щоб стимулювати навчання підприємництву студентів і спонукати на створення високотехнологічних стартапів своїх професорів і викладачів, вбудовується в процес експорту освітніх послуг і в міжнародні колаборації.

3 іншого боку, тягне назад накопичений «багаж»: досить віковий викладацький склад, який упирається будь-яким нововведенням уже тому, що «раніше так не було»; застаріла фізична інфраструктура, включаючи лабораторне обладнання і верстатний парк; низька якість абітурієнтів, які не бажають і часто просто не здатні вчитися у вузі (при середньому балі ЗНО трохи вище «трійки»).

На жаль, багато викладачів сприймають те, що відбувається, не як конвульсії радянської по суті моделі вузу в нових умовах, а як результат 
підступів чи то «глобальної закуліси», чи вітчизняних реформаторів освіти, які зловмисно роблять замах на нашу прекрасну і все ще життєздатну вищу школу. Не розуміє їх і переважна більшість самих університетських працівників: звідси - численні скарги на «університетську бюрократію», на примат зовнішніх показників, що на форумах інтернету отримало назву «хіршеманія».

Сучасний вуз повинен готувати не інженерів для неіснуючих державних підприємств, а фахівців, що володіють, поряд 3 навичками в професії, також здатністю управляти проєктами, приймати на себе ризики, тобто проявляти підприємницькі навички. Відповідно, сучасний вуз повинен багато уваги приділяти вдосконаленню змісту освіти. Працюючи разом 3 регіональними роботодавцями, створюючи спільні майданчики для проєктної діяльності студентів і стимулюючи підприємців і венчурних капіталістів приходити до вузу, стаючи бізнес-коучами i менторами вузівських стартапів. Наприклад, наш університет підписав договор про науково-освітнє співробітництво з Спілкою підприємців Харківської області. Метою договору є забезпечення співробітництва у сфері підготовки фахівців та підвищення кваліфікації слухачів, студентів та викладачів університету 3 питань розвитку, підприємництва та реалізації суспільно корисних ініціатив шляхом участі у проектах, програмах та заходах, які реалізуються університетом та Спілкою підприємців Харківської області.

Вуз повинен вміти діяти проактивно - тобто аналізувати тренди в області науки і вищої освіти і формувати ті елементи власної внутрішньої структури, які стануть тригерами змін. Потрібно звернути увагу на ті види і форми освіти, які поки знаходяться на периферії їхньої уваги - додаткова освіта дорослих, а також навчитися пропонувати частину освітнього контенту своїм студентам факультативно, на платній основі, бо ні в який формат освіти, ні в 2-річну магістратуру, ні в 4-річний бакалаврат, неможливо втиснути все те, що може стати в нагоді студентам на їхньому кар'єрному шляху.

Крім того, вузам слід відмовитися від уявлень про вічність і незмінність напрямів навчання - хоча б тому, що нинішнім випускникам доведеться жити в 
суспільстві, де цикл життя професій істотно скорочується, причому сучасні інформаційні технології (зокрема, блокчейн) зроблять в найближчому майбутньому надлишковими професії, які ще недавно були цілком респектабельні. Кафедри, Центр доуніверситетської освіти і кар'єри, інші структури університету повинні аналізувати «Атлас нових професій», бо майбутнє залежить від прикладених зусиль і його можна створити, майбутнє варіативно, що не виникає з минулого, а залежить від рішень і дій сьогодення. I ось, за підтримки Департаменту освіти Харківської міської ради і у колаборації 3 рухом шкільних «Євроклубів», Центр доуніверситетської освіти і кар'єри започаткували нову школу розвитку для покоління $Z$, яка допомагатиме процесам євроінтеграції на рівні доуніверситетської освіти, використовуючи професійну спеціалізацію саме нашого вишу, - «Європейські урбаністичні студії». Знайомитися з проблемами глобалізації, визначати провідні тенденції в урбаністиці, світові стратегї розвитку міст. Покоління $Z$ знайомиться 3 потрібними професіями для міста майбутнього. Звідси - необхідність поступового переходу до моделі «освітнього супермаркету», в якому «клієнт» вибирає ті продукти, які сам вважає необхідними, а не (тільки) ті, які держава поставила йому в вигляді «освітнього прожиткового мінімуму».

В подальшому, нашим вузам доведеться відмовитися від аксіоми про те, що ядром освітнього курсу є аудиторні лекції, а фундаментом самопідготовки студентів - читання i конспектування підручників. Вже зараз найбільш цілеспрямовані студенти можуть замість курсів (або на додаток до курсів) своїх професорів отримати доступ до світових зірок академії на різних платформах відкритої інтерактивної освіти, а підручник вмирає прямо на наших очах, і його з успіхом витісняють аналогічні ресурси інтернету. Вище ми вже говорили про покоління Z, яке робить ставку не на володіння, а на користування. Вони думають про екологію, раціональне використання природних ресурсів. Це можна пояснити: нам продають речі, в яких вже закладено знос, навіщо брати кредити на покупку приставки, якщо через рік вона морально застаріє, а машина на 80\% потребує серйозних вкладень. 
Метатренди останнього десятиліття показують, що люди хочуть працювати, вчитися, спілкуватися і грати, коли й де вони бажають, інтернет стає глобальною мережею мобільного зв“язку, хмарні технології полегшують швидке зростання он-лайн відео та мультимедіа. Світ стає відкритим - поширюються відкритий контент, відкриті дані, відкриті ресурси, відкриті он-лайн курси. Інтернет постійно закликає нас переосмислити навчання та освіту, зростає доля неформального навчання, переглядаються індивідуальні потреби університетів і сам процес навчання. Відповідно, щоб утримати студентів, вузам потрібно зробити дуже багато - зокрема, значно змінити формат навчального процесу, переглянути сформовану структуру академічного персоналу, провести масове перенавчання частини викладачів, щоб навчити їх використанню нових методів і технологій освіти.

Як зробити все це, перебуваючи в рамках досить жорстких ресурсних обмежень? Тільки одним способом - перебудувавши управлінську модель вузу на засадах підприємництва, тобто пошуку ресурсів (людських, фінансових), яких ніколи не вистачає, на зовнішньому ринку, пропонуючи учасникам цього ринку співпрацю, включаючи і интрапренерства.

Дана діяльність інтрапренер пов'язана 3 подоланням опору «всього старого» в прагненні домогтися того, щоб нові ідеї були прийняті. В університетах підтримка интрапренерства виражається в заохоченні винахідників і новаторів, тобто заохочення своїх співробітників за прояв ініціативи в реалізації нових освітніх, дослідницьких, соціальних та інших проектів, що зміцнюють репутацію і підвищують переговорну силу вузу в спілкуванні з регіональними керівниками і бізнес-структурами.

Викладачі вузів можуть підтримати такого роду зміни, розуміючи, що «новий прекрасний світ» університету буде іншим, але не менш важким; він створить не тільки нові можливості для університетів, а й нові проблеми - в тому числі, буде відбуватися подальше статусне i прибуткове розшарування викладацького складу, що супроводжується переходом значної частини викладачів на непостійні позиції, розширення підтримуючих функцій, типу 
прокторінга (супроводу онлайн-курсів), на противагу «повноцінних» аудиторних занять, конкуренція 3 боку неакадемічних форматів освіти, починаючи з різних онлайн-курсів і закінчуючи корпоративною освітою великих компаній, і багато інших, поки ще не цілком усвідомлених ризиків і небезпек.

Але тільки таким чином можна уникнути головної небезпеки, яка загрожує вищій освіті, - заколисуючи себе минулими досягненнями, залишаючись в колії вищої освіти другої половини ХХ ст., остаточно випасти з контексту сучасних глобальних тенденцій іiі розвитку, про що вже попереджають видатні теоретики освіти.

У центрі «Порядку денного 2030» ООН є 17 Цілей сталого розвитку, що чітко означують світ, якого ми прагнемо для всіх націй без винятків. Нові Глобальні цілі є результатом процесу, що був інклюзивнішим, ніж будь-коли: уряди залучили бізнеси, громадянське суспільство та місцян. Усі ми маємо спільне бачення того, куди має рухатись світ. Реалізація цих амбіцій потребує безпрецедентних зусиль усіх секторів суспільства - i освіта має відіграти надзвичайно важливу роль у цьому процесі. Світ, у якому ми живемо, стає все більш взаємозалежним та складним. Усі ми рухаємося нестійким курсом, використовуючи природні ресурси планети у такому величезному масштабі, що під загрозу ставиться благополуччя наступних поколінь. Вища школа, яка усвідомлює свою відповідальність перед суспільством, відстежує зміни у світі. Одночасно вона намагається знайти гідні відповіді на всі нагальні питання сучасності; прагне підготувати наше спільне майбутнє.

Різноманітність та стійкість світу залежать від розуміння його цілісності та різноманіття, від усвідомлення складної реальності, властивої світові, від розуміння того, які кроки необхідно зробити. Освіта і чітке усвідомлення нашої особистої відповідальності повинні зробити свій внесок у розвиток суспільства, підвищити рівень відповідальності за вибір, який ми здійснюємо, сформувати почуття поваги до інших народів, природи та різноманітності. Наукові дослідження, нові знання повинні вплинути на зміни в освітньому процесі у напрямку визначення того, що свідомо не можна робити, а що потрібно зробити. 
Мета освіти - готовність до спільного майбутнього, постійно мінливого, повного викликів та можливостей.

Яким чином вища освіта реагує на процес глобалізації? Які стратегії вона може запропонувати для сталого розвитку? Відповідь досить банальна i зрозуміла - необхідно переходити до інноваційної моделі розвитку.

Розвиток інновацій, технологій, науковотехнічного прогресу та інтенсифікація народного господарства сьогодні $є$ невід'ємними компонентами стійкого зростання економіки світу. У сучасному ринковому середовищі значну конкурентоспроможність та ефективний розвиток отримали саме інноваційнотехнологічні системи. Імператив інноваційного розвитку України серед ключових ставить завдання модернізації освіти, саме освіта - як система формування інтелектуального капіталу нації та як одна з головних сфер генерації інновацій - створює базові умови для швидкого зростання ринку на основі оновлення технологій та продуктів. Вона виступає першою ланкою в інноваційному ланцюжку «освіта - дослідження - венчурні проєкти - масове освоєння інновацій». Про необхідність кардинальних змін у стратегії розвитку освіти особливо говорити не доводиться: сьогодні про це багато хто пише. Щоправда, «кардинальність» найчастіше обмежується пропозицією «модернізації» (латання дірок). Тим часом, мову потрібно вести про те, що освіті належить стати одним з головних чинників у творенні того суспільства, яке дозволить людству вижити в умовах катаклізмів, що насуваються. Пріоритетним завданням освіти є розвиток і формування у людини таких здібностей, які дозволили б їй комфортно адаптуватися до мінливих соціальних умов $\mathrm{i}$ створювати новий соціальний простір. Вперше ці завдання прозвучали у Доповіді Римському клубу «Немає меж навчанню» у 1979 році ${ }^{28}$. Тоді ж з явився новий термін «інноваційне навчання» як навчання, що стимулює інноваційні зміни у культурі і соціальному середовищі, як реакція на проблемні ситуації, що виникають у житті людини чи суспільства. Ця доповідь констатувала стан кризи, в якому опинилась система сучасної освіти. Спробою подолати цю ситуацію

\footnotetext{
${ }^{28}$ Botkin J.W., Elmanda M., Malitza M., 1979
} 
стали реформи освіти, які були проведені у передових країнах світу: США, Великобританії, ФРН, Японії.

В Україні тільки в останні роки розпочались обговорення й декларування заяв на тему серйозної модернізації освіти. $€$ надія, що слідом за деклараціями 3'являться і конструктивні рішення, і реальні економічні дії на користь модернізації освіти. Швидкозмінна ситуація в глобальному світі висуває до інституту освіти нові вимоги, пов'язані з необхідністю забезпечити інноваційновипереджальний характер підготовки фахівців щодо задоволення потреб як суспільства (у тому числі і стратегічних), так і самої освіти. В цих умовах неминучий перехід від політики модернізації освіти до політики, яка виходитиме 3 уявлення про неминучість його випереджального розвитку.

Вже зараз слід передбачати нові можливості та потреби суспільства. Тим часом ситуація у світовій освіті (включаючи й українську) свідчить про збереження орієнтації іï інститутів на минуле, на передачу і освоєння давно застарілої інформації.

Звернемося хоча б до домінуючих уявлень про зміст навчальної літератури. Як добре відомо, вона орієнтована на викладення матеріалу, перевіреного практикою та теорією. Таке уявлення тісно пов'язане із традиційним тлумаченням освіти як засобу трансляції знань, уміння та навичок від професора до студента. На практиці ж сказане означає, що часто мова йде про циркуляцію в освітньому середовищі застарілих знань і цінностей, які втратили свою значущість. На сторінках підручників і посібників вкрай рідко можна зустріти гіпотези і припущення, які активно обговорюються. Часто студент отримує інформацію про минуле наукового пошуку.

Між іншим, подібний підхід все частіше дає збої. І справа не тільки в тому, що різко збільшився потік інформації (подвоєння кількості інформації відбувається у світі менше ніж за рік), у тому числі й у сфері фундаментальних наук, а ще й тому, що відбуваються такі фундаментальні відкриття, які навіть зруйнують збудований «науковий будинок». Принаймні більшість 3 них свідчить 
про те, що всі отримані людиною знання - лише невелика прибудова до будівлі майбутньої науки.

Через посилення тенденцій переходу до постіндустріального суспільства, швидкість технологічного оновлення виробництва досягла такої величини, що професійні знання стали старіти ще до того, як випускники встигають застосувати їх на практиці. У зв'язку з цим в США була введена спеціальна одиниця вимірювання - «період напіврозпаду компетентності», що показує тривалість часу з моменту закінчення вузу, коли нова науково-технічна інформація викликає зменшення компетентності фахівців на 50\%. Відповідно до їх статистики в американських інженерів випуску 1940 р. знання застаріли наполовину через 12 років, 1960 р. - через 8-10 років, 1970 р. через 5 років. Що стосується сучасності, то цей термін, на думку авторів, обчислюється 2-3 роками $^{29}$.

Трансформація освітнього процесу, мабуть, буде проходити декількома напрямками. У цій статті виділимо лише два досить очевидні. По-перше, зміст освіти має включати найбільш нове, фундаментальне та міждисциплінарно загальне, не чекаючи на той час, коли воно застаріє. Іншими словами, освіта має стати процесом не просто трансляції вже відомого, а процесом, готовим до сприйняття принципово іншого.

Говорячи про майбутню освіту підприємницького університету як інноваційний процес, мається на увазі, що нову інформацію необхідно генерувати не тільки в науці, а й у самому освітньому процесі. Звичайно йдеться, не лише про те, що студенти отримуватимуть більш загальні фундаментальні знання, а й про те, що це нове може виникати і як результат процесу взаємодії викладача та студента з освітнім та життєвим середовищами.

Крім того, освіта як інноваційний процес має бути випереджаючою, що прокладає шлях у майбутнє, в результаті чого вона може стати інноваційновипереджальною, одночасно виступаючи і як освіта для сталого розвитку.

\footnotetext{
${ }^{29}$ Ільїч Л. М. Структурні зрушення транзитивного ринку праці: теорія і методологія регулювання. Кваліфікаційна наукова праця на правах рукопису. Дис. на здобуття наук. ступеня д-ра ек. наук. Ін-т демографії та соціальних досліджень імені М. В. Птухи НАН України, Київ, 2018.
} 
У вирішенні цього завдання корисним може виявитися підхід, що розробляється М. Піщуліним, в рамках якого освіта розглядається не тільки як індивідуальна, громадська, а й загальна світовпорядкова форма розвитку, де еволюціонує весь пов'язаний 3 людиною універсум - соціокультурний, природний, космічний, антропологічний, тобто онтологічний і це, по-друге. ${ }^{30}$

3 погляду онтологічного підходу М. Піщуліна, освіта має на меті формування людини, що лише частково враховується в концепції освіти, яка розглядає останнє в контексті «передачі наукових знань та формування мінімально необхідного для включення до суспільного виробництва набору умінь та навичок розумової роботи» ${ }^{31}$.

Говорячи про майбутнє, важливо мати на увазі суспільство і діяльність людини: для них ця проблема особливо актуальна, на що потім звернув увагу А. Тоффлер ${ }^{32}$. У нашій свідомості міцно утвердилося уявлення, що треба вивчати минуле як предмет (у плані вивчення людського суспільства) історичної науки. Передбачається, що знання минулого формує в людини розуміння сьогодення. Тільки в цьому випадку можна дати адекватну оцінку тому, що відбувається сьогодні, виявити причини, а можливо, і наслідки за умови, що час не виявиться нелінійним феноменом.

Таке розуміння минулого в сучасній культурі, науці та освіті $є$ загальновизнаним. I це справді так, коли розвиток суспільства йде досить спокійно, еволюційно, а зв'язок між минулим, сьогоденням та майбутнім виявляється лінійним. Революції, звичайно, додавали в таке розуміння лінійності часу свій внесок, який частково порушує лінійне мислення. Але, оскільки більш спокійні періоди часу домінували, «аксіома» лінійності також превалювала, що знаходило свій відбиток у багатьох соціальних процесах зокрема й у освіті.

Розуміння освіти як процесу формування особистості тим, що було у минулому, умовно можна назвати його «історичною» інтерпретацією. Таке

\footnotetext{
${ }^{30}$ Пищулин Н. П. Философия образования: законы, доктрина, принципы. М., 2001.265 с.

${ }^{31}$ Куликовская А.В. Дидактика креативного автопоэзиса человека и его знания / Что такое постнеклассическое знание. М. Александров. 2007. с.169.

32 Тоффлер А. Шок будущего / Кравченко А. И. Социология. Хрестоматия. М., 2002. С. 290-315
} 
«історичне» розуміння є цілком прийнятним для періоду, коли людству не загрожують біфуркації у вигляді глобальних катастроф, здатних його занапастити.

Як зазначив колишний Генеральний директор ЮНЕСКО у передмові до книги «Освіта для майбутнього: сім уроків минулого»: «Коли ми дивимось в майбутнє, то виникає чимало сумнівів про той світ, у якому житимуть наші діти, онуки та правнуки. Переконані ми лише в одному: якщо тільки ми дійсно хочемо, щоб ця земля змогла задовольнити потреби іiі мешканців, то суспільство має стати іншим. Світ завтрашнього дня буде істотно іншим порівняно з тим світом, який ми знаємо. Ми маємо створити умови для «стійкого майбутнього» ${ }^{33}$. В результаті система відносин між суспільством і природою, яка існувала раніше, отримала назву моделі нестійкого розвитку.

На конференції ООН з навколишнього середовища та розвитку (1992р.) було запропоновано нову форму (модель) розвитку суспільства - «модель сталого розвитку», перехід до якої, за ідеєю, повинен забезпечити виживання та невизначено довгий розвиток людства в умовах збереження навколишнього природного середовища.

Однак, щоб перейти до нової стратегії, необхідно не лише реалізувати вимоги екологічних імперативів, на що на згаданих форумах ООН було звернено основну увагу, а й кардинально перебудувати всі галузі та напрямки людської діяльності, причому в пріоритетному порядку доведеться трансформувати сучасну освіту. Освіті належить провідна роль: саме освіта зорієнтована на фундаментальні зміни в шляхах, що визначають наше життя та поведінку. Освіта - «сила майбутнього»; вона - у числі найважливіших інструментів змін. При цьому одна 3 найскладніших проблем, 3 якими ми зіткнулися, пов'язана 3 питанням формування такого мислення, яке дозволило б зустріти і відповісти на виклики все більш складного, швидко мінливого і непередбачуваного світу. Має бути заново продуманий сам спосіб організації знання. Останнє передбачає

\footnotetext{
${ }^{33}$ Морин Э.Образование для будущего: семь уроков прошлого / Alma mater. 2008. №3. C. 44-50
} 
руйнування традиційних міждисциплінарних бар'єрів, вихід на нові способи інтерпретації того, що нібито, вже розпалося на частини. Має бути перегляд усієї освітньої політики та змісту навчального процесу. Людина, яка навіть і оволоділа знаннями та культурними досягненнями моделі нестійкого розвитку, не зможе побудувати нове суспільство.

У чому ж полягатиме кардинальна відмінність освіти для сталого розвитку від традиційного? Одностайності думок 3 цього питання поки що не досягнуто. Екологи та представники природничих наук часто вважаючи, що освіта для стійкого розвитку в істотному ступені включитить екологічну складову, розглядають процес становлення освіти для сталого розвитку як перехід від екологічної освіти до утворення в інтересах сталого розвитку. Безсумнівно, розвиток екологічної освіти та екологізація останньої - один із напрямків формування освіти для сталого розвитку. Проте до суттєвого інноваційного перетворення будуть схильні інші види та напрями освітнього процесу економічний, гуманітарний, інженерний тощо, які будуть не лише екологізуватись, a, й головне, все більше акцентуватимуть увагу на майбутньому, тією чи іншою мірою включатимуть майбутнє у процес навчання. Хоча ООН проголосила мету номер чотири: «Забезпечення всеосяжної та справедливої якісної освіти та заохочення можливості навчання протягом усього життя для всіх» ${ }^{34}$.

Зосередивши увагу на минулому і частково теперішньому, світовий освітній процес опинився у ролі застарілого механізму соціально-економічного розвитку. Трансляція застарілого «освітнього знання» від попередніх поколінь до наступних, на що в основному і зорієнтована сучасна освіта, аж ніяк не означає, що вона допомагає вирішувати нагальні проблеми сьогоднішнього дня, а тим більше - завтрашнього. Причина такої ситуації полягає в тому, що вже наявні знання та досягнення культури, які циркулюють в освіті, виявляються не просто застарілими, а є відображенням моделі нестійкого розвитку. Тому,

\footnotetext{
${ }^{34}$ Цілі у сфері сталого розвитку. URL : https://www.un.org/sustainabledevelopment/ru/education/
} 
освітній процес, щоб поступово ставати інноваційним, повинен дедалі більшими темпами включати те, що з'явиться або може з'явитися в майбутньому.

Як навчати тому, чого ще немає і чому нові знання мають з'являтися в освіті? Здивування розсіється, якщо уважно досліджувати процес входження майбутнього та нового у процес освіти.

Оскільки трансляція застарілого знання в освітньому процесі не допоможе переходу до стійкого майбутнього, то, треба кардинальним чином змінити сам цей процес, роблячи його все більш інноваційним, адаптуючи до майбутніх змін, порушуючи традиційну лінійність педагогічного мислення. Адже для виживання людства, його переходу до сталого розвитку важливо включати випереджаючі механізми, механізми передбачення та прогнозування. I якщо вже зрозуміло, що необхідний інноваційний перехід від нестійкого розвитку до сталого, важливо і в освітній процес включити всі існуючі та можливі форми та механізми, які здатні допомогти вирішити цю основну цивілізаційну проблему третього тисячоліття.

Отримання знань - основна проблема. Дійсно, як розвивати шляхи пізнання, щоб забезпечити умови для сприйняття найбільш загальних, фундаментальних проблем та включення приватного, обмеженого знання в індивідуальний контекст?

Домінування фрагментарності, поділу знання на дисципліни часто робить людину нездатною до поєднання частин у ціле. Очевидно, що на зміну такому стану справ має прийти навчання, що передбачає, яким чином можна побачити предмети в їхньому контексті, складності та тотальності.

Отже, потрібно розвивати природну здатність людського розуму включати всю інформацію в певний контекст і цілісність. Іншими словами, необхідно подати такі методи, що дозволяють у складному світі вловлювати взаємовідносини та взаємовплив частин та цілого.

Цілком очевидно, що знання про майбутнє не можуть містити істини та факти, які перевіряються практикою, що реалізується лише в минулому та 
сьогоденні. Майбутнє в цьому сенсі відторгнуто від фактологічної науки, хоча передбачення і прогнозування і є функцією теоретичного рівня пізнання.

У дослідженнях майбутнього, їхньої представленості в освітньому процесі необхідно реалізовувати нові принципи, способи та форми освоєння майбутнього. Одна з форм, що активно розвиваються - моделювання того, що може статися, тобто випереджальне моделювання у різних його формах, особливо за допомогою нових інформаційних технологій. Це той спосіб входження майбутнього в інноваційно-освітній процес, який пов'язаний 3 інформатизацією, оскільки лише на інформаційному рівні можна будувати та вивчати моделі майбутнього як нормативні (типу сталого розвитку) чи як дослідницькі прогнози і передбачення. Тут можливі і лінійні виходи в майбутнє 3 минулого i сьогодення, i нелінійно-інноваційні, або навіть можуть створюватися моделі, що не мають прототипів у минулому чи аналогів у теперішньому. I якщо навчання в минулому грунтується на запам'ятовуванні, то включення до цього процесу випереджуючого моделювання базується на принципах більш творчої, розвиваючої освіти.

Таким чином, майбутній спеціаліст як «синтезатор» знань у різних галузях науки не може відбутися, якщо в його свідомості не утворюються «міжсистемні асоціації», які охоплюють різні системи, утворюючи узагальнені поняття, взаємозв'язки теорій. Відсутність реально налагоджених зв'язків між навчальними дисциплінами призводить до того, що, маючи об'єктивні, достатні знання, студент часто не може перенести їх на вирішення завдань нової дисципліни.

У нашому університеті вже накопичено певний досвід вирішення цієї проблеми через формування узагальнених знань, умінь та навичок, що реалізуються у певних видах діяльності (наприклад, при безперервному проектуванні на спеціальності «Архітектура»). Підсумком роботи в семестрі студентів - архітекторів є захист проєкту, де цілісно, діалектично відображені всі курси, що вивчаються. У цих проєктах представлені всі елементи знань та всі їх відносини, способи отримання та зміни, тобто вони містять не тільки 
узагальнені знання, вміння і навички, а й здібності, i розумові операції, i загальний світогляд. Захист проходить перед комісією, до якої входять усі викладачі, які викладають курси у відповідному семестрі. Це, в свою чергу, мобілізує викладачів на те, що у процесі підготовки архітектора-фахівця йому потрібно дати не тільки «суму знань», як це і прийнято за традиційного навчання, а й сформувати в них систему взаємозалежних знань, які утворюють цілісну, узагальнену структуру.

Викладач у змісті та способі побудови навчального предмета відображає не тільки поняття, закони, теорії та факти, які відповідають науці, а й спосіб мислення, властивий даному етапу його розвитку та ті методи пізнання, які в ній застосовуються. Власне, зміст має бути побудований на нових принципах, у контексті завдання забезпечення умов для сталого розвитку, виходячи з яких у навчальній дисципліні необхідно виявити сутність, яка лежить в основі будьякого приватного явища даної дисципліни, тобто виділити інваріант системного змісту. Фахівець починається там, де доводиться змінювати і застосовувати нові комбінації знань, де починається елемент творчості в малому та великому, або, за термінологією В. Вернадського, де стикається з проблемою побудови цілісної картини з фрагментів, які отримують з різних наук або різних підходів в межах однієї і тієї ж науки.

Ми живемо в умовах дедалі стрімкішого потоку інновацій, інтенсивного розширення та оновлення знань. Швидко з'являються нові спеціальності, зникають старі. За оцінками, нині у світі існує понад сто тисяч спеціальностей, причому їх кількість зростає з кожним роком. Сказане з неминучістю спрричиняє перехід до безперервної освіти, але не варто плутати безперервність 3 наступністю, тобто спочатку - школа, потім - ВН3, а потім - післявузівська освіта. Безперервність означає необхідність постійного підвищення своєї кваліфікації, рівня своєї освіти.

Незважаючи на скепсис прихильників традиційної (контактної) очної форми здобуття освіти, по відношенню до перспективи дистанційного навчання, віртуальні вузи, на думку європейських аналітиків, до 2025 р. стануть основними 
постачальниками вищої освіти. Глобальний ринок електронного навчання у 2015 p. - \$ 107 млрд до 2015 року. (у 2010 році - \$32,1 млрд), темпи річного зростання приблизно 9,2 \% протягом п“яти років. Темпи зростання електронного навчання по країнах: Індія $-55 \%$; Китай $-52 \%$; Малайзія $-41 \% ; \ldots$ Україна $-20 \% .^{35}$

Наприклад, Єльський університет відкрив доступ до своїх навчальних матеріалів. Тепер на сайті університету в розділі «Відкриті курси Сльського університету» можна отримати не тільки програми курсів і всі належні навчальні посібники з них, а також відеозаписи лекцій та їх розшифровки. Вперше такий доступ було відкрито п'ять років тому Массачусетським технологічним інститутом. Входження України до Болонського процесу відкрило шлюзи для відтоку української молоді до вишів Свропи. Вже зараз велика кількість наших студентів навчається у системі дистанційної освіти США, Англії та ФРН. Цього року їхня кількість значно збільшилася у зв'язку з COVID 19. На Азіатському ринку успішно працює Туреччина, яка має мільйонну аудиторію студентів системи відкритої освіти. Їх завдання найближчими роками довести цю цифру до трьох мільйонів осіб. Окрім того, українська освіта практично відсутня на ринках СНД.

У цьому контексті, звісно, на перший план виходить проблема якості освіти. Дуже болюча тема - якість освіти. Якість - останній оплот ретроградів. Щоразу, коли починається щось нове, відразу ж задаються питанням про якість. Але чим визначається якість? Згідно 3 результатами, отриманими американськими дослідниками, якість випускника на 68\% залежить від його генетичних факторів і лише на 32\% - від освітнього середовища навчального закладу.

Таким чином, є два шляхи досягнення високої якості підготовки. Перший орієнтований на здібності студентів, відбираючи найбільш здібних на конкурсній основі, звичайно, можна досягти високої якості підготовки випускників. Обдарована людина - вона і є обдарована: вчи іiі, не вчи - сама

\footnotetext{
${ }^{35}$ Кухаренко В. Тенденції розвитку електронної освіти. URL : http://education-ua.org/ua/analytics/438-tendentsijirozvitku-elektronnoji-osviti-v-2015-r
} 
всьому навчиться. Інший шлях пов'язаний із створенням досконалого освітнього середовища.

Нині серед економічно активного населення України вже близько 20\% мають вищу освіту. За даними психологів, частка досить обдарованих у нас становить близько 5\% у своїй віковій категорії. Таким чином, 16\% від загальної кількості людей 3 вищою освітою - носії середніх здібностей. Висновок очевидний: система вищої освіти має пристосуватись до навчання студентів середніх здібностей.

Хосе Ортега-і-Гассет, іспанський філософ, у роботі «Місія університету» писав, що «інститути існують - необхідні та мають сенс - тому, що існує середня людина. Якби були лише визначні діти, цілком можливо, що не було б ні педагогічних установ, ні громадської влади. Тому необхідно співвідносити будьякі інститути з людиною середніх здібностей: для неї вони створені, вона має бути їхньою мірою» ${ }^{36}$.

Якими можуть бути потреби у вищій освіті в недалекому майбутньому? В умовах постіндустріального суспільства, приблизно 20\% населення повинні мати вищу освіту. На думку професора Давидова, в умовах інноваційної економіки частка людей з вищою освітою має становити вже 60\%. Що стоїть за цією цифрою? Аналізуючи стан освіти в умовах постіндустріальної економіки на прикладі великої та невеликої країни (США та Нідерланди), бачимо, що у сільському господарстві в цих країнах зайнято 4\% населення, у промисловості (включаючи транспорт та зв'язок) - 15\% та $81 \%$ - у сфері послуг, у тому числі приблизно половина зайняті у сфері управління, фінансів, культури, освіти, науки (саме у цих галузях найбільш затребувана вища освіта).

Які зміни відбудуться під час переходу до інноваційної економіки? Сфера послуг дещо зросте (з 81 до 85\%). У цих областях понад 90\% зайнятих повинні мати вищу освіту. Причому, якщо звернутися до прикладів дуже розвинених економік (наприклад, у Японії), то виявиться, що багато робочих посад там уже передбачають вищу освіту. Цей висновок докорінно суперечить нашому

\footnotetext{
${ }^{36}$ Ортега -и-Гассет Х. Миссия университета / Пер.с исп. М.Н. Голубевой. Мн.: БГУ. 2005. С.104.
} 
прагненню розвивати ПТУ та технікуми. У світі технікумів немає. Майже ніхто не користується фахівцями середньої ланки.

В Україні також є постійна тенденція розвитку послуг. Темпи зростання відповідних галузей випереджають динаміку ВВП. Індекс розвитку реалізованих послуг у 2003 році становив 121,0\%, 2004 p. - 131,2, 2005p. - 128,8, 2006 p.126,2\% і 2007 року - 132,0\%, причому така закономірність простежується не тільки щодо загального обсягу послуг, а й сфери реалізації на зовнішньому ринку. Так, у 2007 році експорт послуг становив 9038,9 млн. дол. США, що у 2,6 рази перевищує рівень 2000-го, а питома вага їх в українському експорті - 15,5\%. Незважаючи на те, що розвиток експорту послуг має стійку тенденцію до зростання, можливості України у підвищенні ролі третинного сектора у формуванні нової економіки далеко не вичерпані. Отже, посилення експортної орієнтації сфери послуг має стати головним чинником інноваційної структури економіки нашої країни.

Серед завдань розвитку третинного сектора слід визначити формування лідерських позицій у міжнародній сфері освіти. При цьому варто врахувати, що на світовому ринку конкурують не лише (щодо окремих країн можна стверджувати, що й не так) освітні послуги як такі, як самі суспільства, їх репутація, перспективи та багатовікові культурні традиції. Лідером на ринку сфери освітніх послуг (приблизно 15 млрд. дол. на рік) є США, для яких, як і для колишнього СРСР, вища освіта іноземців - це, скоріше, довгострокова глобальна політика, ніж короткострокова локальна економіка. Попит на освіту зростає у всьому світі. За даними ЮНЕСКО, чисельність студентів за останні 40 років зросла у 6 разів. Якщо у 2000 році у ЗВО світу навчалось 82 млн. осіб, то у 2015 році студентів буде 97 млн., а у 2025 році їх кількість перевищить 100 млн. ${ }^{37}$

Стратегія експорту освітніх послуг України має базуватися на тому, що наша країна як європейська має розвинені навчальні системи, які багато століть

\footnotetext{
${ }^{37}$ Академічна мобільність як фактор інтеграції України у світовий науково-освітній простір. URL : https://niss.gov.ua/doslidzhennya/gumanitarniy-rozvitok/akademichna-mobilnist-yak-faktor-integracii-ukraini-usvitoviy
} 
та особливо в останні десятиліття забезпечували підготовку конкурентноспроможної на світовому ринку робочої сили фахівців. Враховуючи українські реалії, експансія (якщо намагатися концентрувати політику у цьому напрямі) освітніх послуг на зовнішній ринок мала б переслідувати як мінімум такі цілі. По-перше, розширення можливостей для розвитку та утримання інтелектуального потенціалу країни. По-друге, отримання додаткових джерел прориву у науковому просторі. По-третє, розвиток освіти та науки як певного напряму бізнесу.

Не менш важливим викликом глобалізму $є$ ризик втрати духовності людини. Ця загроза виходить із загальної ліберальної стратегії розвитку.

На Родоському форумі 2019 «Глобальний (біс)порядок: на шляху до світоглядів, заснованих на діалозі», у рамках секція «Стратегія освіти ХХІ ст. освіта у нових умовах», мова йшла про панування технократичного знання, завдаючи шкоди знанню гуманітарному, яке якраз і передає смисл того, що відбувається, дозволяє дати йому оцінку і намітити реальні шляхи виходу з тих кризових ситуацій, які ми маємо: глобальні кризи - це криза втрати сенсу в світі людини, екології, демографії, міжцивілізаційних відносин 38 . Виступачі підкреслювали, що технократичне знання не пропонує нам вирішення проблем, які надалі тільки загострюватимуться.

Що нам дають нові знання техніки? Нові знання науки? Дуже багато в плані нашого економічного життя, нашого фізичного існування, комфорту. Але при цьому в технічному прогресі розчиняється сенс та взагалі існування. Олюднення прогресу не відбувається. Тому для вищої освіти визначено такі вектори розвитку:

гуманізація освіти як докорінний поворот від його технократичної мети (забезпечення виробництва кадрами, їх пристосування до потреб виробництва)

\footnotetext{
38 Родоський форум 2019: глобальний (біс)порядок: на шляху до світоглядів, заснованих на діалозі. https://docresearch.org/ru/2019/03/\%D1\%80\%D0\%BE\%D0\%B4\%D0\%BE\%D1\%81\%D1\%81\%D0\%BA\%D0\%B8\%D0\%B9$\% \mathrm{D} 1 \% 84 \% \mathrm{D} 0 \% \mathrm{BE} \% \mathrm{D} 1 \% 80 \% \mathrm{D} 1 \% 83 \% \mathrm{D} 0 \% \mathrm{BC}-2019-$ \%D0\%3\%D0\%BB\%D0\%BE\%D0\%B1\%D0\%B0\%D0\%BB\%D1\%8C\%D0\%BD\%D1\%8B\%D0\%B9$\% \mathrm{D} 0 \% \mathrm{~B} 1 \% \mathrm{D} 0 \% \mathrm{~B} 5 \% \mathrm{D} 1 \% 81 \% \mathrm{D} 0 \% \mathrm{BF} \% \mathrm{D} 0 \% \mathrm{BE} \% \mathrm{D} 1 \% 80 \% \mathrm{D} 1 \% 8 \mathrm{~F} /$
} 
до гуманістичних цілей становлення та розвитку особистості, створення умов для іiі самореалізації;

демократизація освіти як перехід від жорсткої централізованої і однакової системи організації навчання до створення умов і можливостей для кожного вищого навчального закладу, викладача, студента якнайповніше розкрити свої можливості та здібності;

випереджувальний розвиток вищої освіти щодо рівня розвитку виробництва, його техніки й технологій;

прагнення до неперервної освіти як перехід від, «освіти на все життя» до, «освіти впродовж усього життя»;

технологізація освіти як процес упровадження в навчальний процес педагогічних технологій, здатних значно підвищити ефективність освіти; інформатизація освіти як комплекс соціально-педагогічних перетворень, пов'язаних з насиченням освітніх систем інформаційною продукцією, засобами й технологіями.

XXI століття - це століття боротьби культур і людських ресурсів, пов'язаних 3 освітніми системами. Тому освіта має бути переорієнтована 3 інтересів суспільства та виробництва на інтереси й можливості тих, хто навчається. Гуманізація освіти протистоїть іiі технократизації, тобто спрямованості на служіння суспільству й передусім виробництву та науковотехнічному прогресу. Гуманізація освіти означає створення оптимальних умов для всебічного розвитку особистості. Отже, навчання повинне носити особистісно орієнтований характер. Основними характерними рисами такого навчання $€$ :

пріоритет розвитку над навчанням; суб`єкт - суб`єктні стосунки між викладачем і студентами;

знання, уміння й навички як засіб розвитку особистості; використання інтерактивних методів навчання; включення в процес навчання рефлексії, самоаналізу та самооцінювання. 
Гуманізація вищої освіти у поєднанні 3 гуманітаризацією сприяє вихованню у студентів основних компонентів базової структури особистості: культури життєвого та професійного самовизначення;

інтелектуальної, моральної, технологічної, інформаційної, екологічної та інших культур.

Терміни «гуманістичний» $\mathrm{i}$ «гуманітарний» дуже близькі за своїм змістом, проте їх розрізняють у дискусіях про гуманізацію та гуманітаризацію освіти. Гуманізм - «система поглядів, що історично змінюється, яка визнає цінність людини як особистості, їі право на волю, щастя, розвиток і прояв своїх здібностей, яка вважає благо людини критерієм оцінки соціальних інститутів, а принципи рівності, справедливості, людяності бажаною нормою між людьми» 39 . Гуманізм означає систему цінностей, що підносить людську особистість, покладає в основу будь-яких проектів або дій благо і щастя людини, ії невід‘ємні і природні права на гідне життя.

Слово «гуманітарний» міцно закріплене за комплексом наук (гуманітарні науки), предметом яких є ті чи інші прояви людської духовності, тобто за філологією, етикою, філософією, історією, естетикою, юриспруденцією тощо. Відповідно представників цих наук називають гуманітаріями, на відміну від гуманістів, тобто тих людей (безвідносно до їхнього роду занять), що керуються у своїй діяльності гуманістичними ідеалами. Але, разом з тим, загальне кореневе слово (homo), що лежить в основі зазначених термінів, говорить про їхню смислоутворювальну єдність.

Якщо звернутися до вихідного трактування гуманітарних наук, що сходить до великих гуманістів Відродження, то відомо, що під гуманітарними знаннями вони мали на увазі не просте вивчення поезії, риторики, античної філософії (ця інтенція завжди існувала в історії), а дещо більш високе - пізнання мудрості через слово, що підносить людину. Іншими словами, гуманітарні науки лише тоді відповідають своїй споконвічній функції, коли відкривають у людині

\footnotetext{
${ }^{39}$ Токман О.В. Гуманізм як поняття і соціальне явище / Мультиверсум. Філософський альманах. К. : Центр духовної культури. 2004. № 40. http://www.filosof.com.ua/Jornel/M_40/Tokman.htm
} 
особистість, їі неповторність і унікальність, їі найвищу самоцінність, коли вони служать гуманістичним ідеалам.

Тепер можна більш конкретно спроектувати ці терміни на завдання освітнього процесу. Гуманізація освіти буде означати створення такої освітньої соціальної системи, що відповідає гуманістичним цінностям та ідеалам. Гуманітаризація ж освіти означатиме наповнення або доповнення освітньої програми гуманітарним змістом, тобто вона передбачає включення у навчальний процес циклу гуманітарних дисциплін. Отже, бачимо, що концепти «гуманізація освіти» i «гуманітаризація освіти» характеризують дещо різні вектори у реформуванні вищої школи. Якщо «гуманізація освіти» у широкому сенсі означає створення у суспільстві гуманної системи освіти, що відповідає гуманістичним ідеалам (насамперед, особистісній волі, соціальній справедливості і людській гідності), то «гуманітаризацію освіти» пов“язують із навчально-методичним змістом викладання у ЗВО. Гуманітаризація жодним чином не зводиться лише до завдання розширення інформаційного змісту гуманітарних дисциплін порівняно з професійним блоком, але, у принципі, повинна відповідати більш високим цілям: залученню молодих людей до гуманістичних цінностей, до гуманітарної культури людства. Іншими словами, гуманітаризація розглядається як додатковий i необхідний компонент професійної освіти. Так, гуманітаризація освіти переслідує дві основні i взаємозалежні цілі: по-перше, 3 іï допомогою намагаються перебороти «частковість» людини (молодого фахівця), ïi одномірність, що задається професійною підготовкою; по-друге, за допомогою гуманітаризації намагаються закласти у молодого фахівця основи гуманістичного світогляду. Отже, гуманітаризація розглядається як спосіб залучення молодої людини до духовних цінностей цивілізованого світу, як їі окультурення у широкому значенні слова, яке ніяк не зводиться лише до вузької професіоналізації.

Хоча необхідність гуманітаризації зараз ні у кого не викликає сумнівів, зіткнення спостерігаються якраз у питанні гармонізації професіоналізації $\mathrm{i}$ гуманітаризації, у їх збалансованому співвідношенні у межах навчального 
процесу. Варто відзначити, що без якісної професіоналізації не може бути сформований фахівець, професіонал у своїй справі, i, таким чином, навчання у ЗВО взагалі втрачає свій сенс. Однак, без гуманітаризації не може бути сформована повноцінна особистість.

Професія допомагає людині функціонально включитися у соціум, у розгалужену систему суспільної діяльності. Однак, крім цієї функціональної адаптації до соціуму через професію людина повинна ще органічно увійти до простору культури, засвоїти іï смисл і цінності, у процесі чого формується духовність людини, їі світогляд, розуміння нею свого місця і ролі суспільстві.

Поза цією духовністю ми маємо обмежену, неповноцінну людину, функціонера у заданій системі суспільного поділу праці.

Особистість - це завжди, насамперед, індивідуальність, яка формується у культурі і на основі культури. Вона є спадкоємницею і одночасно творцем культури. Професія наповнюється людським змістом для особистості лише тоді, коли за нею виявляється щось більш високе і самоцінне, а саме: надбання своєї індивідуальності у багатогранному і суперечливому світі культури, свого неповторного «людського обличчя».

Гуманізм в освіті здебільшого i повинен сприяти самовираженню особистості у світі культури, іiі вільному самовизначенню. Допомогти у цьому свідомому виборі майбутньому молодому фахівцю і повинна продумана гуманітаризація освіти. Отже, гуманітаризація виявляється органічно пов 'язаною з гуманізацією. Гуманітаризація повинна відкривати перед молодою людиною найвищий сенс культури, вводити їі у простір світової культури. Особливо гострою нині є проблема гуманітаризації технічної освіти, трудової підготовки молоді.

Проблеми гуманізації та гуманітаризації освіти в Україні найбільш повно висвітлені у працях С. У. Гончаренка, який наголошував, що проблеми гуманізації «останнім часом стали особливо актуальними у зв'язку з новим розумінням мети освіти, яка має забезпечити розвиток здібностей цілісної особистості, необхідних і їй, і суспільству, залучення іï до активної участі в 
житті, поєднання буття індивідуальної людини 3 культурою» ${ }^{40}$. На думку науковця, гуманізація передбачає становлення та вдосконалення унікальної цілісної особистості, яка прагне до максимальної реалізації своїх можливостей, відкрита для сприймання нового досвіду, здатна на свідомий і відповідальний вибір у різноманітних життєвих ситуація ${ }^{41}$.

Вища школа має надати таку освіту, яка у подальшому давала б можливість вчитися самостійно, стимулювала б у студента необхідність у самоосвіті та самовдосконаленні для власного інтелектуального зростання, для підвищення освіченості й становлення інтелігентності.

Для успішного розв'язання проблеми гуманітаризації, для прискорення процесу проникнення гуманітарної культури у зміст технічної освіти, необхідні:

1) забезпечення методологічної єдності у викладанні гуманітарних i спеціальних дисциплін;

2) переорієнтація фахових дисциплін на гуманістичну спрямованість, у центрі якої стоїть особистість;

3) організаційно-структурні зміни у системі освіти та виховання студентів, викладання навчальних дисциплін максимально наблизити до реальних, змінних умов життя;

4) гуманітаризація всього освітнього процесу у В3О, а саме: посилення ролі гуманітарних дисциплін за рахунок створення міцних міжпредметних зв'язків; підвищення рівня етичного та естетичного виховання студентів; активізація інтересу студентів до вивчення вітчизняної історії, світової культури та загальної психології.

Поряд із посиленням професійної підготовки майбутнього фахівця перше місце має посідати розвиток особистості, зорієнтований на загальнолюдські інтереси та цінності, формування високого почуття патріотизму. Проте виховання технічної інтелігенції неможливе без подолання технократичного

\footnotetext{
${ }^{40}$ Гончаренко С. У. Український педагогічний енциклопедичний словник. 2-ге вид., доповн. й виправл. Рівне: Волин. обереги, 2011. 519 с.

${ }^{41}$ Там же, с. 131.
} 
підходу до освіти і посилення гуманітарного впливу на весь перебіг навчального процесу.

Одним із суттєвих недоліків професійної підготовки майбутнього фахівця є недостатнє залучення студентів до діяльності у художній сфері, відсутність мотивації до підвищення культурного рівня, умов і засобів активації їхнього духовного, творчого потенціалу. У результаті професійна освіта втрачає культурний, моральний та особистісний контекст і значення.

Одним із чинників подолання технократизму у вищій школі вважаємо створення культурно-художнього середовища. Уже в стародавні часи була провідною ідея про елементи естетики і краси праці у творчій діяльності людини. Деякі стародавні філософи бачили у праці джерело краси й закликали творити красу, перебудовуючи світ. Вивчення культури та традицій свого народу допомагають розвинути свідомість і почуття особистості, а зокрема почуття патріотизму, іiі стійкі погляди та переконання. Тому лише усвідомлення себе продовжувачем справи багатьох поколінь, гордість за свій народ, уміння бачити красу освіти і красу праці, можуть стати тією моральною основою, яка дозволить викладачеві формувати у студентів любов до праці, природи, свого народу, своєї країни.

Отже, гуманізація та гуманітаризація освіти є перспективними засобами підвищення ефективності вищої школи і об‘єктивною соціальною потребою. Ці концепти хоча й характеризують дещо різні вектори у реформуванні вищої освіти, але в своїй органічній єдності можуть розглядатися як додатковий i необхідний компонент професійної освіти, і мають за мету допомогти студенту, як повноцінному суб‘єкту динамічних і суперечливих суспільних процесів, у формуванні наукової інтелектуальної культури, громадянської гідності, соціальної саморефлексії, постійного нарощування духовного й творчого потенціалу.

Демократизація - ще один з провідних векторів розвитку вищої освіти. Демократизація освіти будується на таких принципах: самоорганізація навчальної діяльності студентів, співпраця викладачів і студентів, різноманіття 
освітніх систем, рівні можливості у здобуванні освіти, громадсько-державне управління. Демократизація сприяє реалізації права кожної людини на освіту, незалежно від іiї соціального стану, статі, національності, релігійної та расової належності.

Головне у новій парадигмі освіти - це орієнтація на інтереси особистості, адекватні сучасним тенденціям розвитку суспільства, визнання унікальної сутності кожного студента та індивідуальності його навчальної траєкторії. А тому перспективним напрямом оптимізації освітнього процесу у вищій школі є ефективне впровадження особистісно зорієнтованих технологій (технологізація освіти).

У суспільстві поширена точка зору, відповідно до якої наднизький рівень народжуваності обумовлений соціально-економічними проблемами, невлаштованістю побуту та іншими труднощами, що наповнюють наше суспільство. Однак соціологи, які досліджують сімейно-родинні відносини, довели, що основна причина депопуляції пов'язана зі змінами в репродуктивних установках людей, викликаних змінами в ціннісних орієнтирах сучасної людини.

Коли досягнення науки і техніки пов'язані з вищими потенціями людини, ми є свідками справжнього прогресу. Коли ж вони зав'язані на масовій культурі, на суспільстві споживання та інстинктах, властивих масовій культурі, то ми бачимо, що історія рухається вперед і вгору, вперед і вниз.

Саме тому важливо розуміти роль гуманітарного знання. У розумінні зв'язків між релігією, філософією, історією, літературою, мовою, вони дозволяють бачити те, що відбувається, не повторюючи того, що було в історії, яка породжувала свої суперечності та безвиході. Тому важливе завдання гуманітарного знання полягає в тому, щоб займатися не тільки інноваціями, промисловістю, машинобудуванням, а й людинобудуванням: майбутнє залежить від того, що відбувається у внутрішньому світі людини. Тому-то такий важливий синтез наукових і культурно-історичних знань, який би розроблявся в цілісну освітню систему. 
Гуманітаризація технічної освіти в вузі не пов'язана 3 майбутньою професією, але за своєю значимістю для формування фахівця з вищою освітою, для становлення особистості вона в ряді випадків може виявитися навіть більш значущою, ніж підготовка власне за основним фахом. При аналізі цієї складної проблеми ми неминуче зіткнемося з поняттям «світова культура», форми якої не тільки різноманітні, а й надзвичайно великі. I ніхто не може точно сказати, що і скільки треба знати інженеру з вищою освітою, крім знання металознавства, зварювання тощо, щоб претендувати на статус «інтелігента» з усіма властивими цьому поняттю якостями.

Освічені люди - таке базове уявлення про інтелігенцію. I з ним мало хто сперечається.

Як соціальне явище люди, які здобувають освіту для роботи головою за допомогою рук, а не руками за допомогою голови, формуються паралельно 3 розвитком індустріального капіталізму. У поділі суспільних функцій, що склався, вони є виробниками знання; зайняті організацією чужої праці; керуванням ними; розподілом одержаних результатів.

У постіндустріальному, інформаційному суспільстві жива фізична праця мінімізувалась. Управління, розподіл, організація/ дезорганізація стало масовим заняттям; будь-які знання та компетенції продаються на ринку, в результаті інтелігенція як особливий шар соціуму поступово зникає. Якщо, працюючи замість рук мовою, більшість населення «виробляє дискурси», то інтелігенції як конкретного соціального власника розуму більше немає. Перемігши i, по суті, ототожнившись із соціумом, вона розчиняється в масі.

Якщо на Заході працівники розумової сфери, як правило, не претендували на вихід за межі своїх професійних обов’язків, в кращому випадку дозволяючи собі критикувати владу, то в нашій історії, вони культивували ідеали відповідальності перед народом, навіть поклоняючись йому; брали на себе місію його освіти; піклувалися про щастя суспільства і навіть про долю людства вцілому. 
Людина культури не може бути просто знаючою, інтелектуальною: вона має бути ще й соціально залученою, моральною, тобто бути «інтелігентом». Ї̈̈ думка у найширшому значенні цього слова вплетена в життя. Ця історична особливість самосвідомості вітчизняних освічених верств визнана у світі i, як відомо, у багатьох іноземних словниках слово «інтелігент» маркується позначкою «рос.».

Інтелігент не відокремлює себе від нижчих соціальних груп. Більше того: він стурбований їхніми проблемами. Узагальнено кажучи, він орієнтований на принцип служіння, принцип, який лежить в основі духовності, це - людина зі світоглядом, ціннісним, а не тільки пізнавальним чи технологічним ставленням до світу. Йому недостатньо гарного виконання своєї професійної ролі: він хоче проєктувати те, що існує.

У контексті панівної нині ліберальної ідеології не передбачається ціннісних - релігійних і моральних - регуляторів соціальності. Вона не передбачає ніякого «служіння», а керується лише принципом розумного егоїзму, взаємної вигоди та обміну. Тим самим відмовляється від культури як способу «внутрішнього» духовного освоєння світу людиною і позиціонує себе як цивілізація.

У цьому суспільстві особистість трансформується в «актора», в діяча і ділка, який у всьому керується раціональними міркуваннями, в інтелектуала. Відмова від культури та особистості означає, відповідно, кінець інтелігентності як прояву особистісних та культурних характеристик буття освічених людей.

Інтелектуал - це актор, ділова людина, зайнята у сфері розумової праці. Він - глибокий теоретик, який знає свою конкретну справу, високий професіонал, але він не вважає за потрібне і можливе думати про суспільство в цілому, його болі і проблеми. У нього є розум, але немає світогляду, що виражається зовні, i пов'язаних з ним переживань, а його духовність перетворювалася на менталітет. Перед нами - теоретичний прагматик або, що все одно, прагматичний теоретик. Якщо в остаточній формі елементи духовності все-таки зберігаються, то для приватного користування. 
Узагальнюючи, можна сказати, що якщо інтелігент - це суб'єкт культури, духовності, служіння і моралі, то інтелектуал - суб'єкт науки і техніки, носій раціоналізму та технологій. Зрозуміло, сказане - ідеалізація; очищене від емпіричних протиріч моделювання поточних явищ, але воно дозволяє зрозуміти напрямок їх розвитку та оцінити, що несе людству переважання того чи іншого ідеалу, припустити результат їх взаємодії.

Життя, на щастя, не до кінця логічне і можна бачити, як, зокрема в Україні, що спрямувалась в ринок шляхом глобалізму та цивілізації, національні традиції та культура борються, опираються. Занадто сильна традиція і позитивна аура інтелігентності.

Таким чином, університет 3.0 розширює спектр соціальних і економічних гравців - це і великі компанії, i малі фірми, і мережеві організованості, i некомерційні організації. Університет 3.0 - інституційна форма для здійснення цілого пакета діяльностей, при цьому природничо-наукових і інженерних знань вже недостатньо, розгортаються нові предметності - знання про економіку і ринки, про соціум і культуру.

В університеті 3.0 на перший план виходять навчальні і наукові підрозділи економічного і технологічного профілю. В університеті 3.0 крім раціонального обгрунтування, потрібне власне проектування діяльності всіх компонентів, відповідно, важливими предметами стають управління змінами; менеджмент і управління інноваціями; цифровий технічний дизайн. Університет 3.0 протистоїть «індустріальним» університетам з їх інертним освітнім процесом, який включає стандартні пакети курсів, які швидко стають застарілими; він проблематизує їх академічне середовище. «Матеріальне тіло» Університету 3.0 включає, крім аудиторій, бібліотеки, лабораторій, також бізнес-інкубатори і технопарки, конструкторські бюро, проектні офіси, спеціальні майданчики для комунікацій із зовнішнім світом - виставкові простори, громадські центри. Вища школа, діалектично пов'язуючи освіту та виховання, зберігає традиції підготовки інтелігенції, опираючись переходу до інтелектуалізму. 